\title{
BIZARRO STATUTORY STARE DECISIS
}

\author{
by \\ Jamie Darin Prenkert*
}

ABSTRACT: In Smith v. City of Jackson, the Supreme Court applied to the Age Discrimination in Employment Act one of its decisions interpreting Title VII of the 1964 Civil Rights Act, which Congress had overridden with the Civil Rights Act of 1991. It treated Wards Cove Packing Co. v. Atonio, dealing with disparate impact theory and burdens of proof, as a binding interpretation of the ADEA, despite that Congress expressed disapproval of Wards Cove. The Court relied on two interpretive approaches to arrive at this result: the presumption that identical language in the ADEA and Title VII should be interpreted consistently and the strong presumption of statutory stare decisis. This convergence of circumstances led to the odd result of duplicating the congressionally disfavored Wards Cove interpretation.

I use the comic book story of Bizarro, Superman's imperfect duplicate, as an allegory for the Smith Court's flawed invocation of statutory stare decisis to duplicate Wards Cove, labeling it Bizarro statutory stare decisis. None of the justifications for the regular presumption of statutory stare decisis supports the result in Smith. Furthermore, Bizarro statutory stare decisis interferes with the proper balance of power between Congress and the Court and implicates the countermajoritarian difficulty of elevating the Court's interpretations over Congress's expressed preferences. The paper explores other contexts in which Bizarro statutory stare decisis could wreak havoc.

Finally, I present an alternative to Bizarro statutory stare decisis. In situations like Smith, the Court should not treat an overridden interpretation as binding precedent, but should interpret the statute before it as a matter of first impression. In doing so, an overridden interpretation should not be duplicated without clear textual, purposive, or historical evidence that the overridden interpretation is more appropriate this time around. The paper concludes by applying this alternative to Smith and explaining why Wards Cove should never have been revived.

\footnotetext{
* Assistant Professor, Indiana University, Bloomington, Indiana. B.A Anderson University, 1995; J.D. Harvard Law School, 1998. Copyright 2006 Jamie Darin Prenkert. All rights reserved.
} 
TABLE OF CONTENTS

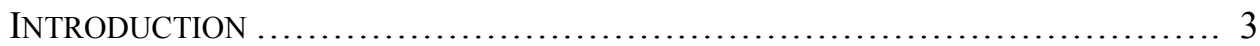

I. THE HISTORY OF DISPARATE IMPACT: THE BIZARRO BACKSTORY ......... 8

A. Disparate Impact Theory Under Title VII .............................. 8

1. Griggs v. Duke Power Co. and its early progeny: Recognizing and refining disparate impact ................................... 8

2. Watson v. Fort Worth Bank \& Trust: Foreshadowing Wards Cove's retrenchment .............................................. 11

3. Wards Cove Packing Co. v. Atonio: Limiting disparate impact .......................................... 15

4. 1991 Act: Overriding Wards Cove ............................ 17

B. Disparate Impact Theory Under ADEA (Pre-Smith) ...................... 18

1. Before Hazen Paper Co. v. Biggins: General recognition............ 19

2. After Hazen Paper: Circuits Split ............................... 19

II. THE INTERPLAY OF TWO PRESUMPTIONS: THE DUPLICATING RAY AND THE ORIGINAL "SUPER" POWER .................................................. 20

A. The Consistency Presumption: Duplicating

Prior Interpretations .............................................. 20

B. Statutory Stare Decisis: The "Super-Strong Presumption"............. 21

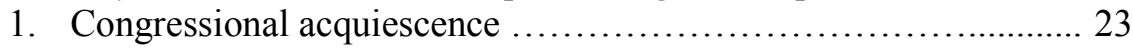

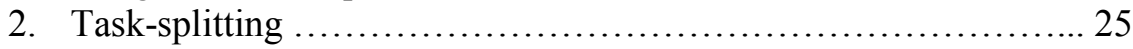

3. Separation of powers ..................................... 26

a. Constitutionally-compelled .............................. 26

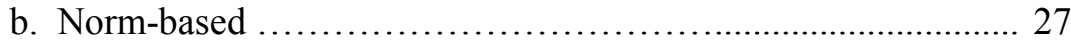

4. Reliance, Continuity, and Coherence ....................... 28

III. The SMITH DECISION: THE ORIGIN OF BIZARRo STATUTORY STARE DECISIS AND WHY IT IS BIZARRO ............................. 30

A. The Smith Opinion ..................................................... 30

B. The Bizarro Nature of Smith's Reasoning (or Lack Thereof) ............. 34

1. Congressional Acquiescence .................................. 35

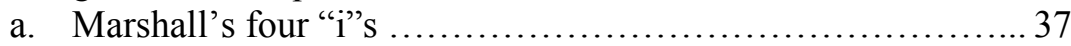

b. Constitutional concerns ................................... 40

2. Task-splitting ............................................... 40

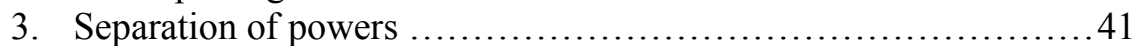

4. Reliance, continuity, and coherence ......................... 42

IV. THE LONG-TERM IMPACT OF BIZARRO STATUTORY STARE DECISIS: BIZARRO GOES EXPLORING ......................................... 43

A. The Effects of Bizarro Statutory Stare Decisis: A Shift in the Balance of Power ..................................................... 43

B. An Example: Price Waterhouse and the Mixed-Motive Case .......... 44

V. AN Alternative APPROACH: PUtTING BIZARro TO REST ............... 51

CONCLUSION .......................................................... 55 
"[W] hen Congress uses the same language in two statutes having similar purposes, particularly when one is enacted shortly after the other, it is appropriate to presume that Congress intended that text to have the same meaning in both statutes."

--Smith v. City of Jackson, 544 U.S. 228, 233 (2005).

"While the relevant 1991 amendments expanded the coverage of Title VII, they did not amend the ADEA or speak to the subject of age discrimination. Hence, Wards Cove's pre-1991 interpretation of Title VII's identical language remains applicable to the ADEA."

--Smith v. City of Jackson, 544 U.S. 228, 240 (2005)

"What am me?"

--Bizarro

\section{INTRODUCTION}

In Smith v. City of Jackson, ${ }^{1}$ the Supreme Court of the United States relied on, incorporated, and applied a prior decision which had been overridden $^{2}$ by Congress in the Civil Rights Act of 1991 (the "1991 Act"). ${ }^{3}$ It treated Wards Cove Packing Co. v. Atonio, ${ }^{4}$ an opinion interpreting Title VII of the 1964 Civil Rights Act ("Title VII"), ${ }^{5}$ as binding precedent for fashioning the disparate impact theory of recovery ${ }^{6}$ under the Age Discrimination in Employment Act of 1967 ("ADEA"). ${ }^{7}$ Justice Stevens, writing for the Court in Smith, used language evoking the doctrine of

\footnotetext{
1544 U.S. 228 (2005).

2 In this paper, I use the terms "override," "overriding," and "overridden" as it is used in William N. Eskridge, Jr., Overriding Supreme Court Statutory Interpretation Decisions, 101 YALE L.J. 331, 332 n.1 (1991) [hereinafter, Eskridge, Overriding]("This article will use the term "override" to mean any time Congress reacts consciously to, and modifies a statutory interpretation decision."). In contrast, "overrule," "overruling," or "overruled," as used in this paper and by Eskridge, refers to Supreme Court reversal of its prior statutory interpretation decision. See William K. Eskridge, Jr., Overruling Statutory Precedents, 76 GEO. L.J. 1361 (1988) [hereinafter Eskridge, Overruling].

${ }^{3}$ Pub. L. No. 102-166, 105 Stat. 1071 (codified as amended in scattered sections of 42 U.S.C.).

${ }^{4} 490$ U.S. 642 (1989).

${ }^{5} 42$ U.S.C. $\$ \S 2000 \mathrm{e}-2000 \mathrm{e}-17$ (2000).

${ }^{6}$ See, e.g., Griggs v. Duke Power Co., 401 U.S. 424 (1971). See also infra Part I for a general overview of the disparate impact theory of discrimination under federal antidiscrimination laws.

729 U.S.C. $\S \S 621-634$ (2000).
} 
enhanced statutory stare decisis, ${ }^{8}$ which the Court often applies to its statutory interpretation decisions. ${ }^{9}$ Based on the presumption that ADEA language that was "derived in haec verba" from Title VII should be interpreted the same as Title VII, the court relied on its Title VII interpretations to interpret the ADEA. ${ }^{10}$ Because Congress did not amend the ADEA in response to Wards Cove as it had Title VII, the Court treated that congressional inaction as an adoption of the Wards Cove interpretation for the ADEA. ${ }^{11}$ Yet, this was no normal implementation of statutory stare decisis. It was at best an imperfect duplicate, sharing some characteristics with the traditional form, but mutated and problematic. As such, the statutory stare decisis employed in Smith bears a striking metaphorical resemblance to the comic book character Bizarro. Smith has introduced a new doctrine to the statutory interpretation milieu: Bizarro statutory stare decisis.

In the Superman comic series, Bizarro is a recurring character. ${ }^{12} \mathrm{~A}$ likely homage to Frankenstein's monster, ${ }^{13}$ Bizarro is an imperfect replica of Superman, created by a faulty "duplicating ray."14 Bizarro's looks, dress, and abilities resemble Superman. ${ }^{15} \mathrm{He}$ also shares some of

8 Smith, 544 U.S. at 240 ("While the relevant 1991 amendments expanded the coverage of Title VII, they did not amend the ADEA or speak to the subject of age discrimination. Hence, Wards Cove's pre-1991 interpretation of Title VII's identical language remains applicable to the ADEA.").

9 See Amy Coney Barrett, Statutory Stare Decisis in the Courts of Appeals, 73 GEO. WASH. L. REV. 317, 319 (2005) (describing the doctrine of statutory stare decisis).

${ }^{10}$ Smith, 544 U.S. at 234.

${ }^{11} I d$. at 240.

${ }^{12}$ What follows is an overly-simplified version of the Bizarro mythos, relying mostly on the "Silver Age" incarnation of Bizarro. As with most comic book characters, Bizarro's appearances in various comic book series over the years create a multi-layered and complex (as well as arguably internally contradictory) biography. I hope true fans of the Superman comic books will allow me to simplify and streamline the story a bit. In return, I hope I have not butchered it too badly in the simplification.

${ }^{13}$ See generally MARY SHELLEY, FRANKENSTEIN (Simon \& Schuster 2004) (1818).

${ }^{14}$ In his many incarnations, Bizarro is typically created by someone (e.g., Lex Luthor or a scientist acquaintance) shooting Superman with a "duplicating ray," either accidentally or purposefully. See, e.g., Otto Binder, Superboy, in THE GREATEST SUPERMAN STORIES EVER TOLD 115-17 (John Byrne and Mike Gold eds., 1987) (Professor Dalton creates Bizarro by accidentally hitting Superboy with his malfunctioning "duplicator ray"). The duplicating ray creates a copy of Superman, but Bizarro is an "imperfect duplicate." He often is depicted with a pasty complexion, angular rock-like features, and wearing a copy of the traditional Superman outfit (though the "S" emblem on his chest is often backwards). See Superman Super Site, Bizarro, http://www.supermansupersite.com/bizzarro.html (Last visited Aug. 29, 2006).

${ }^{15}$ The many appearances of Bizarro in the Superman comics share a few common threads. One is his odd grammar. Bizarro typically uses only the accusative case pronouns "me," "him," "her," and "them" and conjugates verbs incorrectly. See Binder, supra note 
Superman's memories and sensibilities. ${ }^{16}$ In his early comic book appearances, Bizarro is not the opposite of Superman. ${ }^{17} \mathrm{He}$ is not evil; he is simply a mutation. He has elements of Superman, but he is imperfect. ${ }^{18}$

From this origin, the word Bizarro has developed a distinct modern usage as a descriptor. It refers to an imperfect version or mutation of something. Though the "Bizarro" version shares aspects of the original, it is not the original. And, usually, it is seriously flawed. ${ }^{19}$

Like the Bizarro character, the origin of Bizarro statutory stare decisis is the result of an odd convergence of circumstances. In general, where the ADEA and Title VII have identical language, the Court will treat a decision interpreting one as a binding interpretation of the other. ${ }^{20}$ This is where the

14 passim. Another is the origin of the name "Bizarro." Always, shortly after his creation, someone describes him as "bizarre." Superman Home Page, Superman: Special Reports: Bizarro, http://www.supermanhomepage.com/comics/comics.php?topic=specialreports/bizarro (last visited Aug. 29, 2006). In the original Superboy comic, Superboy comments, "Gosh, that creature is bizarre." To that, Bizarro responds, "Him call me . . . Bizarro. Is ... Is that my name?” See Binder, supra note 14, at 117.

${ }^{16}$ For instance, in his initial appearance in Superboy, Bizarro tries to go "home" to the Kent farm, but feels rejected when his "mom" asks him to leave. Id. at 120. Bizarro also pines for Lois Lane, as does Superman, and kidnaps her. Lois is saved when she turns the duplicating ray on herself and creates Bizarro-Lois. See Superman Home Page, supra note 15.

${ }^{17}$ Readers familiar with the television series Seinfeld will recall the episode in which Elaine meets a group of three friends who are, in many respects, the opposite of her friends Jerry, George, and Kramer. Jerry surmises that Elaine's new friends are the "Bizarro" version of himself, George and Kramer. See Seinfeld: The Bizarro Jerry (NBC television broadcast October 3, 1996). A short video clip from the episode, including a reference to "Bizarro world" by Elaine can be found at http://www.sonypictures.com/tv/shows/seinfeld/site/player/player.html?path=../video/prom os/0803 (last visited July 31, 2006). This understanding of Bizarro comes from his more recent appearances in the Superman comics, in which his manner of speaking is no longer marked only by the third person accusative, but also by saying the opposite of what he means. Furthermore, in these more recent appearances, Bizarro's behavior is intended to be evil, rather than confused or misguided. See, e.g., Superman Homepage, Who's Who in the Superman Comics: Bizarro, http:/www.supermanhomepage.com/comics/who/whointro.php?topic=bizarro (last visited Aug. 29, 2006).

${ }^{18}$ See Don Markstein's Toonpedia, Bizarro, http://www.toonopedia.com/bizarro1.htm (Last visited Aug. 29, 2006) ("Comics writer Alvin Schwartz, who scripted the Superman newspaper strip in the 1950s, said many years later that he saw the Superman character, at that time, as a creature of radiant light, and conceived Bizarro as sort of a dark Superman — not evil, as opposed to Superman's goodness, but a Superman without radiance.”)

${ }^{19}$ See Superman Super Site, supra note 14.

${ }^{20}$ Smith v. City of Jackson, 544 U.S. 228, 233-34 (2005) ("[W] same language in two statutes having similar purposes, particularly when one is enacted shortly after the other, it is appropriate to presume that Congress intended that text to have the same meaning in both statutes. We have consistently applied that presumption to language in the ADEA that was 'derived in haec verba' from Title VII." (internal citations omitted)). 
mutation of the statutory stare decisis logic takes root in Smith. It is the duplicating ray, if you will.

Congress enacted the 1991 Act in part to repudiate several Supreme Court decisions from the Court's October 1989 term, including Wards Cove, which narrowly interpreted the disparate impact theory of recovery under Title VII. The 1991 Act explicitly overrode Wards Cove's interpretation of Title VII. It rejected Wards Cove specifically and quickly. But, because Wards Cove interpreted language that was identical to (some of $)^{21}$ the ADEA's language at issue in Smith, the Court treated Wards Cove as controlling precedent for the ADEA, despite its clear repudiation in the Title VII context. The doctrine of statutory stare decisis arguably supports the Court's interpretive move. Yet, it is more than a bit odd for the Supreme Court to treat Congress's silence with regard to the ADEA in the 1991 Act as Congress's explicit approval of an interpretation it had overridden nearly a decade and a half earlier. The combination of the presumption of consistent interpretation of Title VII and the ADEA and the acquiescence justification for the strong presumption of statutory stare decisis, ${ }^{22}$ resulted in an unreasoned and unsound (i.e., Bizarro) interpretation of the ADEA.

Notably, the Smith Court's creation of Bizarro statutory stare decisis is not destined to be a unique occurrence. Just as Bizarro was allowed to roam, wreaking havoc along his way, Bizarro statutory stare decisis could be used in other contexts, including those involving the application of other overridden interpretations of Title VII to the ADEA. If allowed to flourish, this Bizarro version of statutory stare decisis would place the onus on Congress to amend every statute to which the Supreme Court could theoretically extend an erroneous or misguided interpretation, when Congress sets about to correct the Court's mistakes.

This paper describes why Bizarro statutory stare decisis is a flawed interpretive approach. The Smith Court's reliance on it to revive Wards Cove was misguided and failed to serve the purposes generally thought to be served by the doctrine of statutory stare decisis. ${ }^{23}$ As an alternative, this paper advocates that the Court approach situations like that in Smith as requiring interpretation of the statutory language in the first instance, with due care not to revive congressionally overridden interpretations without substantial justification.

In Part I, the paper provides the background for the Smith decision's

21 The ADEA's "reasonable factor other than age" defense in section 4(f)(1) is an exception. See 29 U.S.C. 623(f)(1) (2000). Title VII has no similar defense. See Parts III and $\mathrm{V}$, infra, for discussions of the significance of that textual difference.

${ }^{22}$ See infra Part II.B.1 for a fuller description of the acquiescence justification.

${ }^{23}$ See infra Part III.B. 
creation of Bizarro statutory stare decisis. ${ }^{24}$ In particular, it discusses the several landmark cases in which the Supreme Court recognized, endorsed, and fashioned the disparate impact theory under Title VII, culminating in Wards Cove. Then, it discusses the congressional repudiation of Wards Cove in the 1991 Act. Finally, Part I discusses the history of the application of the disparate impact theory under the ADEA leading up to the Smith decision, which unfolds in two chapters: (1) consistently and without controversy, relatively speaking, prior to the Supreme Court's decision in Hazen Paper Co. v. Biggins ${ }^{25}$ and (2) chaotically and inconsistently following that decision.

Parts II and III tell the story of the origin of Bizarro statutory stare decisis and what makes it "Bizarro." In particular, Part II describes the two essential elements to the creation of Bizarro statutory stare decisis: the consistency presumption $^{26}$ and statutory stare decisis. ${ }^{27}$ This part also briefly describes the various justifications for the doctrine of statutory stare decisis. Part III.A then discusses the Court's opinion in Smith, with primary focus on the resurrection of Wards Cove's interpretation of the structure of and evidentiary burdens in a disparate impact case. Part III.B explains why Smith's Bizarro statutory stare decisis fails to fulfill the various justifications in support of a strong presumption of statutory stare decisis described in Part II.B.

Part IV highlights the problems that likely will result if Bizarro statutory stare decisis is allowed to take root. The confusion regarding the mixedmotives theory of discrimination and the overridden interpretation of Title VII in Price Waterhouse v. Hopkins ${ }^{28}$ provides a concrete example of a context in which Bizarro statutory stare decisis could again play a decisive and destructive role in the interpretation of the ADEA. ${ }^{29}$

Finally, Part V provides an alternative approach to interpreting statutes like the ADEA in Smith, without resort to Bizarro statutory stare decisis. I argue that the Court should undertake an interpretation of such language as

24 Part I, thus, parallels the Superman mythos, which is essential to a full understanding of the Bizarro story.

${ }^{25} 507$ U.S. 604 (1993).

26 The consistency presumption parallels the duplicating ray in the Bizarro story. While the comic book context allows one to suspend disbelief and accept the existence of the duplicating ray despite its questionable science, the consistency presumption requires a bit of explication. Part II.A provides the metaphorical "specs" for the consistency presumption duplicating ray.

${ }^{27}$ In the allegory to the Bizarro story, statutory stare decisis represents Superman. It is the original "super" power, see infra note 111 and accompanying text, from which the imperfect, Bizarro power is derived.

28490 U.S. 228 (1989).

${ }^{29}$ This part parallels the destruction Bizarro caused when he was allowed to roam the city on his own. 
it would in the first instance. Though the Court need not necessarily adopt the amended statute's approach, it should be cautious not to adopt the overridden interpretation without specific textual, purposive, or historical indicators that the overridden interpretation is even more compellingly appropriate in the subsequent statutory context (in this case, the ADEA) than it was in the original statute (in this case, Title VII). Part V concludes with an explanation of how my recommended approach would have played out in the Smith case.

\section{THE History OF Disparate IMPACT: THE BIZARRO BACKSTORY}

The story of the evolution of the disparate impact theory is important to set the stage for why the Supreme Court's creation of Bizarro statutory stare decisis in Smith was unwarranted and doctrinally dangerous. This section will discuss the genesis and development of the disparate impact theory under Title VII in the Supreme Court through the Wards Cove decision. Then, it will describe the congressional reaction to Wards Cove in the 1991 Act. In the second part of this section, the federal courts' application of disparate impact under the ADEA prior to the Smith decision will be described.

\section{A. Disparate Impact Theory Under Title VII}

Few would argue that Congress had anticipated the specifics of disparate impact theory when it enacted Title VII. However, disparate impact garnered the attention of the federal courts shortly after Title VII's enactment and attracted controversy.

1. Griggs v. Duke Power Co. ${ }^{30}$ and its early progeny: Recognizing and refining disparate impact

Although disparate treatment claims are more common, and perhaps because disparate treatment is "the most easily understood type of discrimination," 31 one of the Supreme Court's first forays ${ }^{32}$ into interpreting

${ }^{30} 401$ U.S. 424 (1971).

${ }^{31}$ Int'l Bhd. of Teamsters v. United States, 421 U.S. 324, 335 n.15 (1977). The ease by which disparate treatment may be understood is belied by the continuing attention commentators and courts devote to the difficult questions raised by disparate treatment theory. See, e.g., Charles A. Sullivan, Disparate Impact: Looking Past the Desert Palace Mirage, 47 WM. \& MARY L. REV. 911, 916-925 (2005) (describing the "motive-intent question" and trait discrimination as seriously complicated issues that disparate treatment theory raises).

${ }^{32}$ Technically, Griggs was the second Title VII case to reach the Supreme Court. 
Title VII dealt with a disparate impact claim. In Griggs, a group of African-American employees challenged their employer's practice of requiring a high school diploma and passing scores on standardized tests as conditions for hire or transfer to various departments. ${ }^{33}$ While the employer had a history of overt discrimination against black applicants in its hiring practices and segregation in its assignments to departments, it abandoned those policies and practices prior to Title VII's effective date in $1965 .^{34}$ Nevertheless, the graduation and standardized test requirements tended to perpetuate the status quo. Black employees were still largely segregated in the lowest paid department. ${ }^{35}$ Notably, neither the high school graduation requirement nor the standardized test requirement was shown to - or intended to - isolate workers with particular ability to learn or to perform the jobs for which they were used as screening devices. ${ }^{36}$ Instead, the purpose of the requirements was to maintain "the overall quality of the workforce." $" 37$ Yet, workers who had not graduated from high school and who had not passed the standardized tests were able to perform the jobs satisfactorily. ${ }^{38}$

Because the diploma and standardized testing requirements screened out a "markedly disproportionate" number of black employees, ${ }^{39}$ the Court addressed whether the requirements could violate Title VII. The Court interpreted section 703(a)(2) of Title $\mathrm{VII}^{40}$ as authorizing such disparate

Phillips v. Martin Marietta Corp., 400 U.S. 542 (1971), preceded Griggs by approximately three months. The two cases were argued before the Court within a week of each other. Phillips, which involved a claim by a woman who was denied an employment opportunity because she had preschool-aged children even though fathers of preschool-aged children were not similarly denied the opportunity, was a short per curium opinion. Id. at 543 . The Supreme Court's opinion vacating and remanding the case, stated "[t]he Court of Appeals therefore erred in reading . . . section [703(a)] as permitting one hiring policy for women and another for men -- each having pre-school-age children." Id. at 544. Phillips is considered the foundation for the theory of "sex-plus" or "gender-plus" discrimination. See Devon W. Carbado and Mitu Gulati, The Fifth Black Woman, 11 J. OF CONTEMP. LEGAL ISSUES 701, 722 (2001) ("Phillips established what is now referred to as the sexplus doctrine.").

${ }^{33}$ Griggs, 401 U.S. at 427-28.

${ }^{34} \mathrm{Id}$. at 427.

${ }^{35} \mathrm{Id}$.

${ }^{36} I d$. at 431 .

${ }^{37}$ Id.

${ }^{38} \mathrm{Id}$. at $431-32$.

${ }^{39} \mathrm{Id}$. at 429.

${ }^{40} 42$ U.S.C. $\$ 2000 \mathrm{e}-2(\mathrm{a})(2)$ (2000).

It shall be an unlawful employment practice for an employer . . . to limit, segregate, or classify his employees or applicants for employment in any way which would deprive or tend to deprive any individual of employment opportunities or otherwise adversely affect his status as an employee, because of 
impact claims, even in the absence of an employer's intent to discriminate. The Court focused on the consequences of employment practices instead of the motivation for them, ${ }^{41}$ accepting the lower court's finding that the employer had not intentionally discriminated against the black employees by implementing the requirements. Nevertheless, the Court determined that intent was not required when a non-job-related policy or practice had discriminatory effects. ${ }^{42}$ The meat of the Court's reasoning is in the following passage:

[Title VII] proscribes not only overt discrimination but also practices that are fair in form, but discriminatory in operation. The touchstone is business necessity. If an employment practice which operates to exclude Negroes cannot be shown to be related to job performance, the practice is prohibited. ${ }^{43}$

Thus, the concept of "business necessity" became central to evaluating whether a neutral policy with discriminatory results is prohibited under Title VII. $^{44}$

Over the next fifteen years a body of case law developed adding nuance to the general outline of the disparate impact claim announced in Griggs. ${ }^{45}$ In general, however, the basic structure and the allocation of burdens of a disparate impact claim remained consistent. ${ }^{46}$ The plaintiff had to prove a prima facie case by producing statistical evidence of a disparate impact, which was caused by some neutral employment practice. Then, the burden Id. such individual's race, color, religion, sex, or national origin.

${ }^{41}$ Griggs, 401 U.S. at 432.

${ }^{42}$ Id. ("We do not suggest that either the District Court or the Court of Appeals erred in examining the employer's intent; but good intent or absence of discriminatory intent does not redeem employment procedures or testing mechanisms that operate as "built-in headwinds' for minority groups and are unrelated to measuring job capability.")

${ }^{43} I d$. at 431.

${ }^{44} I d$.

${ }^{45}$ Disparate impact claims heard by the Supreme Court in this period included Connecticut v. Teal, 457 U.S. 440 (1982) (finding actionable disparate impact claim if some policy, practice, or procedure results in adverse impact, even if ultimate "bottom line" employment numbers evidence no imbalance); Dothard v. Rawlinson, 433 U.S. 321 (1977) (extending disparate impact claims to height and weight restrictions that had an adverse impact on the basis of gender and requiring close correlation between the standard and job performance); Washington v. Davis, 426 U.S. 229 (1976) (holding that the Constitution's Equal Protection Clause does not include a Title VII-type disparate impact claim, but instead requires proof of discriminatory intent); Albemarle Paper Co. v. Moody, 422 U.S. 405 (1975) (requiring validation of tests to show job relatedness).

${ }^{46}$ But see Earl M. Maltz, The Legacy of Griggs v. Duke Power Co.: A Case Study in the Impact of a Modernist Statutory Precedent, 1994 UTAH L. REV. 1353, 1370-71 (arguing that the business necessity and job related requirements were inconsistently applied in the courts during this time). 
shifted to the employer to justify the necessity of the challenged practice. In the late 1980s, however, that all changed.

\section{Watson v. Fort Worth Bank \& Trust ${ }^{47}$ : Foreshadowing Wards Cove's retrenchment}

After the relatively straightforward process of maturation during the first decade and a half after Griggs, disparate impact theory experienced major growing pains on the eve of its metaphorical passage into adulthood. Just shy of Griggs's eighteenth birthday, the Supreme Court issued a fractured opinion in Watson, ${ }^{48}$ which recognized that subjective or discretionary employee selection practices or procedures could be the basis for disparate impact claims. ${ }^{49}$ Notably, however, in the plurality portion of her opinion, Justice O'Connor offered a re-imagining of the allocation of the burdens on the parties to a disparate impact case. As such, Watson foreshadowed the retrenchment found in Wards Cove and set the stage for the 1991 Act's disparate impact amendment.

Clara Watson, an African-American woman, worked as a bank teller for Fort Worth Bank \& Trust. ${ }^{50}$ Over the course of a couple of years Watson applied for at least four separate open positions at Fort Worth, all of which would have been promotions. ${ }^{51}$ She was not chosen to fill any of the vacancies. In each case the person who was hired was white. ${ }^{52}$ Fort Worth had no formal, objective criteria or procedures for evaluating applicants for the types of positions to which Watson applied. Rather, Fort Worth relied on the subjective judgment of supervisors who were familiar with the

${ }^{47} 487$ U.S. 977 (1988).

48 Justice O'Connor penned an opinion that was part-majority and part-plurality. The eight members of the Court who participated in the consideration and decision of the case agreed as to the judgment and agreed that disparate impact claims pursuant to Title VII could be based on subjective or discretionary employee selection practices, but four of the justices refused to join what Justice Stevens called the plurality's "“fresh' interpretation of [the Court's] prior cases applying disparate impact analysis to objective employment criteria." Id. at 1011 (Stevens, J., concurring).

49 Prior to Watson the Supreme Court had only endorsed and applied the disparate impact model to objective criteria, such as educational requirements, standardized tests, and height and weight requirements. See, e.g., Teal, 457 U.S. at 443 (written test); New York City Transit Authority v. Beazer, 440 U.S. 568, 570 (1979) (prohibition against methadone users); Dothard, 433 U.S. at 323-24 (height and weight requirements); Davis, 426 U.S. at 234-35 (test of verbal skills); Albemarle, 422 U.S. at 410-11 (written aptitude test); Griggs, 401 U.S. at 425-26 (high school diploma and standardized testing requirements).

\footnotetext{
${ }^{50}$ Watson, 487 U.S. at 982.

${ }^{51} \mathrm{Id}$.

${ }^{52} I d$.
} 
applicants and with the positions in question. ${ }^{53}$

Watson filed suit against Fort Worth alleging race discrimination on behalf of a class of "blacks who applied to or were employed by [Fort Worth] on or after October 21, 1979 or who may submit employment applications to [Fort Worth] in the future."54 The lower court held that Watson's case was inappropriate for disparate impact, due to the subjective nature of the hiring and promotion process. ${ }^{55}$ Justice O'Connor envisioned the Court's task in Watson as follows: "In order to resolve this [split in the circuits], we must determine whether the reasons that support the use of disparate impact analysis apply to subjective employment practices and whether such analysis can be applied in this new context under workable evidentiary standards." Court to answer: (1) does disparate impact analysis apply to subjective practices at all?; and, (2) if it does, how must the burdens be allocated between the parties and what evidence must each produce?

With regard to the first question, all of the participating justices agreed that disparate impact analysis could be applied to subjective selection practices. ${ }^{57}$ The justices recognized that Griggs and its progeny could too easily be subverted and effectively nullified if a strict subjective/objective line were drawn, applying disparate impact only to the latter. ${ }^{58}$ Moreover,

${ }^{53} \mathrm{Id}$.

${ }^{54} I d$. at 983 .

55 Though the lower courts' energies were largely focused on whether the class could be properly certified and, if so, whether Watson was an appropriate class representative, $i d$. at 983-84, the ultimately important issue was whether disparate impact analysis properly could be applied to Watson's claim since the promotion process was one of nearly unfettered discretion given to the relevant supervisors. The United States Court of Appeals for the Fifth Circuit held that "“a Title VII challenge to an allegedly discretionary promotion system is properly analyzed under the disparate treatment model rather than the disparate impact model."' Id. at 984 (quoting Watson v. Fort Worth Bank \& Trust, 798 F.2d 791, 797 (1986)). The Fifth Circuit's holding created a split among the circuit courts regarding the application of disparate impact analysis to discretionary or subjective hiring or promotion procedures. Id. (citing contrary holdings in Atonio v. Wards Cove Packing Co., 810 F.2d 1477 (9 $9^{\text {th }}$ Cir. 1987) (en banc); Griffin v. Carlin, 755 F.2d 1516, 1522-25 $\left(11^{\text {th }}\right.$ Cir. 1985)). The Supreme Court granted certiorari to resolve that question. Id. at 985.

${ }^{56} \mathrm{Id}$. at 989.

${ }^{57}$ Id. at 989-990. See also id. at 1000 (Blackmun, J., concurring).

${ }^{58} I d$. at 989. For instance, Justice O'Connor noted that, regardless of where the line between subjective and objective procedures were drawn, procedures involving a mix of the two would by necessity fall on the subjective side of the line. Therefore, if disparate impact analysis were only applied to objective criteria, an employer could insulate its reliance on written tests, diploma requirements, or height and weight restrictions by making them formally non-determinative (though practically determinative) and adding a subjective interview step to the process. Id. at 989-90. But see generally Michael Selmi, Was the Disparate Impact Theory a Mistake?, 53 UCLA L. REV. 701 (arguing that the expansion of disparate impact theory to practices other than objective criteria, primarily 
the justices saw nothing inherently different in a disparate impact from an objective criterion and one resulting from a subjective process. In both cases, a facially neutral practice, which was not intentionally discriminatory, could nevertheless produce discriminatory results. ${ }^{59}$

The unanimity of the justices broke down, though, as Justice O'Connor proceeded to the next step in her analysis, namely, the allocation of the evidentiary burdens in a disparate impact claim. The plurality for which Justice O'Connor was writing found meaningful differences between objective and subjective practices when considering that Griggs was traditionally understood to require the employer to justify a challenged practice by proving business necessity and job relatedness. ${ }^{60}$ While objective tests can be justified through formal validation studies, the plurality was concerned that employers would not be able to likewise "validate" subjective criteria or processes. ${ }^{61}$ The plurality was concerned that the application of disparate impact to subjective criteria would lead employers to adopt quotas in order to avoid shortfalls which would in turn require the employers to prove that their subjective processes were necessary, but without the benefit of validation studies. ${ }^{62}$

To alleviate the burden on employers to justify their subjective practices and to avoid the perceived Hobson's choice of disparate impact liability or quotas, the plurality revisited and refined the evidentiary standards of a disparate impact case. In particular, the plurality stated that bare statistical disparities in the workforce would be insufficient to support a prima facie case of disparate impact. ${ }^{63}$ Rather, the plurality claimed that the plaintiff had the burden to identify the particular employment practice that caused the adverse impact, ${ }^{64}$ which is often much easier when only objective

testing and seniority cases, was a mistake in that it frustrated the development of an expansive concept of intent under disparate treatment theory).

${ }^{59} \mathrm{Id}$. at 990.

${ }^{60}$ Once a statistically and legally significant disparate impact was shown, Griggs and its progeny shifted the burden to the employer to justify the challenged practice. See id. at 991 (citing Albemarle, 422 U.S. at 426; Griggs, 401 U.S. at 431). See also supra Part I.A.1.

${ }^{61} I d$.

${ }^{62}$ Id. at 992. But see Eric Schnapper, Statutory Misinterpretation: A Legal Autopsy, 68 Notre DAME L. REV.1095, 1130-33 (1993) (describing this concern about quota avoidance as a "vampire argument," in which an objection to legislation that was rejected when Congress enacted it is revived as courts insist the objection must be accounted for in the interpretation of the legislation).

${ }^{63} \mathrm{Id}$. at 994.

${ }^{64}$ The plurality noted that the statistical evidence of adverse impact must be reliable, significant, and appropriately suited to show a causal connection between the challenged practice and the ultimate exclusion of members of a protected group. Id. at 994-95. The plurality declined, however, to set any particular threshold shortfall requirement, instead 
criteria are involved than when subjective criteria are used alone or in combination with objective criteria. ${ }^{65}$ In other words, the plurality would not allow a multi-factored or multi-step process to be subject to a disparate impact claim, even if the statistical evidence of exclusion of members of a protected class were stark, unless the plaintiff could isolate the particular criterion, practice, or procedure that caused the impact.

Second, the plurality argued that the plaintiff should at all times retain the ultimate burden of proof of discrimination. Despite language in prior cases suggesting otherwise, ${ }^{66}$ the plurality stated that, when the employer has produced "evidence that its employment practices are based on legitimate business reasons," 67 the plaintiff should have the burden to prove that other selection devices or practices could meet the employer's legitimate interest without the undesired adverse impact. ${ }^{68}$

The concurring justices took issue with the plurality's construction of the burdens. ${ }^{69}$ Justice Blackmun's concurrence, joined by Justices Brennan and Marshall, criticized the plurality's allocation and description of the evidentiary burdens. It argued that the plurality's construction departed from precedent and undermined Congress's desire to prohibit practices that result in discriminatory effects as well as to prohibit intentionally discriminatory decisions. ${ }^{70}$ In particular, Justice Blackmun argued that a plaintiff should be required only to show the prohibited discriminatory effects by appropriately significant statistics. After that, the employer should bear the burden of justifying the practice that caused the disparate impact, whether objective or subjective. ${ }^{71}$

claiming that a case-by-case approach was preferable. $I d$. at 995 n.3.

${ }^{65} I d$. at 994.

${ }^{66}$ See, e.g., Dothard, 433 U.S. at 329 (requiring employer to "prov[e] that its tests are "job related"); Griggs, 401 U.S. at 432 ("Congress has placed on the employer the burden of showing that any given requirement must have a manifest relationship to the employment in question.").

${ }^{67}$ As Justice Blackmun explained in his concurrence, this formulation seems to reflect the McDonnell Douglas/Burdine formulation of the shifting burdens in a disparate treatment case rather than a disparate impact claim and indicates that the employer has only the burden of producing evidence indicative of job relatedness rather than a burden of proving that the challenged practice is necessary. Watson, 487 U.S. at 1001-02 (Blackmun, J., concurring).

${ }^{68} \mathrm{Id}$. at 998.

${ }^{69}$ Justice Stevens objected to the discussion wholesale, arguing it was unnecessary to address the evidentiary standards, as the Court had answered the question presented regarding the applicability of disparate impact to subjective criteria in the affirmative. Id. at 1011 (Stevens, J., concurring). He saw no benefit to discussing evidentiary burdens in the abstract.

${ }^{70}$ Id. at 1002 .

${ }^{71} I d$. The disagreement between the plurality and the concurring justices also revolved around the type of evidence - and ease with which that evidence could be shown - that 
Because there was no majority opinion regarding the question of evidentiary burdens, the stage was set for a clarification. The plurality's reallocation of the burden of proof to the plaintiff and the requirement to identify specific practices with significant statistical evidence of causation set the stage for the majority's retrenchment in Wards Cove.

\section{Wards Cove Packing Co. v. Atonio ${ }^{72}$ : Limiting disparate impact}

The wait for clarification was short. The Court heard Wards Cove the next term. A class of workers at a salmon cannery in Alaska claimed that their employers ("the canneries") discriminated against them on the basis of their race, raising both disparate treatment and disparate impact claims. ${ }^{73}$ The workers claimed that the hiring and promotion practices ${ }^{74}$ of the canneries resulted in a racially segregated workforce and limited the opportunities of the class based on their race. ${ }^{75}$ In the lower courts the disparate treatment claims were rejected, but the disparate impact claims raised several issues that Watson left unresolved. ${ }^{76}$ The Supreme Court granted certiorari to determine definitively the proper evidentiary standards of a disparate impact analysis. ${ }^{77}$

This time a bare majority ostensibly adopted the approach of Justice

could justify a challenged subjective practice. The plurality argued that validation of subjective criteria was nearly impossible and suggested that showing a connection between the criteria and the employment would be relatively easy. Id. at 998-99. The concurrence argued that validation was not impossible and that evidence other than formal "validation studies," such as expert testimony and historically documented success, could be presented to support subjective criteria. Id. at 1006-07 (Blackmun, J., concurring). Furthermore, the concurring justices argued that justifying subjective or discretionary criteria would often be more challenging rather than easier as the plurality had suggested. Id. at 1008-09.

72490 U.S. 642 (1989).

${ }^{73} \mathrm{Id}$. at 648 .

74 Specifically, the employees challenged the canneries' following hiring and promotion practices: "nepotism, a rehire preference, a lack of objective hiring criteria, separate hiring channels, [and] a practice of not promoting from within." Id at 647.

${ }^{75}$ The canneries were located in remote areas of Alaska. Id. at 646. The workforce was divided into unskilled "cannery jobs" and primarily skilled "noncannery jobs," which were uniformly higher paying than the cannery jobs. Id. at 647 Local and Filipino (nonwhite) workers dominated the cannery jobs, while the noncannery skilled positions were primarily filled by white Washingtonians and Oregonians who were hired in the offseason at the canneries' mainland offices. Id.

${ }^{76}$ Though beyond the scope of this paper, the Court also clarified what sort of statistical comparison would be sufficient to make out a prima facie case of disparate impact. Id. at 650 (noting that the plaintiff's evidence of a significant imbalance in the racial make-up of the two classes of workers was insufficient to support a prima facie case without reference to the expected balance based on the qualified relevant labor force).

${ }^{77} I$. 
O'Connor's plurality opinion in Watson. First, the Court required a disparate impact plaintiff to identify the specific challenged employment practice and to show that it caused a disparate impact on the basis of a protected category. ${ }^{78}$ By creating this specific causation requirement, the Court sought to spare employers from "being potentially liable for "the myriad of innocent causes that may lead to statistical imbalances in the composition of their work forces." ",79

Second, the Court adopted Justice O'Connor's allocations of the burdens of production and persuasion after the plaintiff has established its prima facie case. In particular, the Court held that the burden of persuasion remains with the plaintiff at all times. ${ }^{80}$ The Court required the employer to respond to the prima facie case by producing evidence of its business justification for the challenged practice; however, the employer was not required to show that the practice was "essential" or "indispensable." 81 That construction is notable for two reasons: (1) as the Court admitted, prior precedent suggested that the burden of proof (both production and persuasion) shifted to the employer upon the employee's prima facie showing of disparate impact ${ }^{82}$ and (2) even with the lower burden of production, the court changed the description of that burden from "business necessity" 83 to "business justification." 84

Finally, if the employer produced evidence of a business justification, the employee could still prevail by showing that equally effective alternative practices served the employer's legitimate employment goals

\footnotetext{
${ }^{78} I d$. at 657 ("As a general matter, a plaintiff must demonstrate that it is the application of a specific or particular employment practice that has created the disparate impact under attack.").

${ }^{79}$ Id. (quoting Watson, 487 U.S. at 992).

${ }^{80} I d$. at 659.

${ }^{81} I d$.

${ }^{82} \mathrm{Id}$. at 660 ("We acknowledge that some of our earlier decisions can be read as suggesting otherwise. But to the extent that those cases speak of an employer's 'burden of proof' with respect to a legitimate business justification defense, they should have been understood to mean an employer's production - but not persuasion - burden." (internal citations omitted)).

${ }^{83}$ See, e.g., Griggs, 401 U.S. at 431 ("The touchstone is business necessity." (emphasis added)).

${ }^{84}$ Wards Cove, 490 U.S. at 659. Interestingly, the Court used Griggs's "touchstone" phrase, but substituted justification for necessity. Then, it specifically held that the justification must be more than insubstantial, but need not be "essential" or "indispensable." Id. The Court's verbal formula for business justification was that the "challenged practice [must] serve[], in a significant way, the legitimate employment goals of the employer." Id. That was a far less exacting standard than the business necessity formulation previously endorsed by the Court and applied by the lower courts. Though, in fairness, there was substantial variation in applying the standard among the lower courts prior to Wards Cove. See infra note 91.
} 
while reducing the impact on the protected class. ${ }^{85}$ But, not just any alternative would do. The employee's alternative must have been known to and rejected by the employer. ${ }^{86}$ Furthermore, the Court determined that issues such as efficiency, cost, and other burdens were relevant to determining whether the alternative practice was in fact equally effective. ${ }^{87}$

\section{1991 Act: Overriding Wards Cove}

Congress quickly responded to Wards Cove's restrictive interpretation of the disparate impact claim. As part of the 1991 Act, Congress amended Title VII, adding section $703(\mathrm{k}){ }^{88}$ The amendment was a purposeful repudiation of Wards Cove's construction of the disparate impact claim. ${ }^{89}$

${ }^{85}$ Wards Cove, 490 U.S.. at 660-61.

${ }^{86}$ Thus, the employer's rejection "belie[s] a claim . . . that [the] incumbent practices are being employed for nondiscriminatory reasons." Id. at 661.

${ }^{87}$ Id.

${ }^{88} 42$ U.S.C. $\$ 2000 \mathrm{e}-2(\mathrm{k})(2000)$. In relevant part, section $703(\mathrm{k})$ reads:

(k) (1) (A) An unlawful employment practice based on disparate impact is established under this title only if-

(i) a complaining party demonstrates that a respondent uses a particular employment practice that causes a disparate impact on the basis of race, color, religion, sex, or national origin and the respondent fails to demonstrate that the challenged practice is job related for the position in question and consistent with business necessity; or

(ii) the complaining party makes the demonstration described in subparagraph (C) with respect to an alternative employment practice and the respondent refuses to adopt such alternative employment practice.

(B) (i) With respect to demonstrating that a particular employment practice causes a disparate impact as described in subparagraph (A)(i), the complaining party shall demonstrate that each particular challenged employment practice causes a disparate impact, except that if the complaining party can demonstrate to the court that the elements of a respondent's decisionmaking process are not capable of separation for analysis, the decisionmaking process may be analyzed as one employment practice.

(ii) If the respondent demonstrates that a specific employment practice does not cause the disparate impact, the respondent shall not be required to demonstrate that such practice is required by business necessity.

(C) The demonstration referred to by subparagraph (A)(ii) shall be in accordance with the law as it existed on June 4, 1989, with respect to the concept of "alternative employment practice."

(2) A demonstration that an employment practice is required by business necessity may not be used as a defense against a claim of intentional discrimination under this title.

Id.

${ }^{89}$ See Section 105 of the 1991 Act, which includes the amendment quoted supra at note 88 , makes an interpretive memorandum the exclusive legislative history for that amendment. The memorandum proclaims that the terms "business necessity" and "job 
Specifically, the amendment allows the plaintiff to establish a disparate impact based on the employer's decisionmaking process as a whole, if the process cannot be separated to isolate the specific, individual parts to be challenged. $^{90}$ Also, the amendment adopts the "job related" and "business necessity" standards over the "business justification" and "legitimate interests" standards in Wards Cove. ${ }^{91}$ Finally, the 1991 Act clearly placed the burden of proving business necessity on the employer, ${ }^{92}$ overriding Wards Cove's allocation of the mere burden of production on the employer at that stage. ${ }^{93}$

Of particular note here, the 1991 Act did not amend or even refer to the ADEA with regard to disparate impact claims.

\section{B. Disparate Impact Theory Under ADEA (Pre-Smith)}

The history of disparate impact analysis under the ADEA prior to the Supreme Court's Smith opinion unfolds in two stages. Prior to 1993, the lower courts generally assumed that disparate impact analysis could be employed under the ADEA, just as Title VII. ${ }^{94}$ In 1993, however, the Supreme Court's decision in Hazen Paper v. Biggins ${ }^{95}$ challenged that assumption. The ensuing dozen years saw relative chaos in the lower courts regarding the application of disparate impact under the ADEA and the circuit courts splintered, ${ }^{96}$ until Smith resolved the issue.

related" in the 1991 Act "reflect the concepts enunciated by the Supreme Court in Griggs $v$. Duke Power Co., 401 U.S. 424 (1971), and in other Supreme Court decisions prior to Wards Cove Packing Co. v. Atonio, 490 U.S. 642 (1989)." 137 Cong. Rec. S15276 (daily ed. Oct. 25, 1991) (Statement of Sen. Danforth).

${ }^{90} 42$ U.S.C. $\$ 2000 \mathrm{e}-2(\mathrm{k})(1)(\mathrm{B})(\mathrm{i})$.

91 Id. $\S 2000 \mathrm{e}-2(\mathrm{k})(1)(\mathrm{A})(\mathrm{i})$. Some commentators have suggested, though, that the adoption of the standard of job relatedness and business necessity only incorporated preWards Cove doctrinal confusion. See, e.g., Maltz, supra note 46, at 1370-71 ("Ultimately, Congress chose not to resolve the apparent conflicts in the case law. Legislators instead adopted compromise language ... At the same time, the legislative history on this issue explicitly states that the Civil Rights Act simply reinstates the law as it existed prior to 1989."); Linda Lye, Comment: Title VII's Tangled Tale: The Erosion and Confusion of Disparate Impact and the Business Necessity Defense, 19 BERKELEY J. EMP. \& LAB. L. 315, 335 (1998) ("In essence, the 1991 Act codified the confusion which formerly prevailed.").

9242 U.S.C. $\$ 2000 \mathrm{e}-2(\mathrm{k})(1)(\mathrm{A})(\mathrm{i})$ and (k)(1)(B)(ii).

${ }^{93}$ See supra notes 80-82 and accompanying text.

94 See Smith v. City of Jackson, 544 U.S. 228, 236-37 (2005) ("Indeed, for over two decades after our decision in Griggs, the Courts of Appeal uniformly interpreted the ADEA as authorizing recovery on a 'disparate-impact' theory in appropriate cases.").

95507 U.S. 604 (1993).

96 See Smith, 544 U.S. at 237 n. 9 (collecting authorities). See also Dennison Keller, Note: Older, Wiser and More Dispensable: ADEA Options Available Under Smith v. 
1. Before Hazen Paper Co. v. Biggins: General recognition

Lower courts uniformly assumed that Griggs and its progeny applied with equal force to the ADEA, because Title VII and the ADEA shared the same relevant text. ${ }^{97}$ In fact, a number of courts even followed lead of the 1991 Act's amendments to Title VII, adopting the business necessity defense in the ADEA context. The EEOC's interpretive guidelines endorsed the application of disparate impact under the ADEA and incorporated the business necessity defense as well. ${ }^{98}$ The Supreme Court's 1993 opinion in Hazen Paper upset that uniformity.

In Hazen Paper, Biggins claimed that his employer violated the ADEA when it terminated him in an attempt to keep his pension fund from vesting. ${ }^{99}$ Biggins was 62 years old and would have been an expensive pensioner. Though the Supreme Court recognized that the decision to terminate Biggins prior to his vesting date was correlated with his age, it was motivated by his years of service and the high cost of his pension rather than his age. ${ }^{100}$ As a result, the Court held that Biggins's disparate treatment claim failed, because the employment decision was based on a factor other than age. ${ }^{101}$

In dicta, the Court specifically mentioned that its decision should not be interpreted as deciding whether disparate impact claims based on criteria correlated with age could be successful under the ADEA. ${ }^{102}$ Justice Kennedy's concurrence, however, explicitly stated that the ADEA might not allow such disparate impact claims. ${ }^{103}$

\section{After Hazen Paper: Circuits Split}

Though the Supreme Court had not definitively decided the issue, a number of lower courts interpreted Hazen Paper as a repudiation of the disparate impact theory as applied under the ADEA. A split in the circuit

Jackson: Desperate Times Call for Disparate Impact, 33 N. Ky. L. REV. 259, 268 (2006) (collecting cases illustrative of the split).

${ }^{97}$ See supra note 40 and infra note 109 and accompanying text. This was ultimately the position taken by the Court in Smith. See Smith, 544 U.S. at 234.

${ }^{98}$ See id. at 239.

${ }^{99}$ Hazen Paper, 507 U.S. at 606-07.

${ }^{100} I d$. at 610.

${ }^{101} \mathrm{Id}$.

${ }^{102} \mathrm{Id}$.

${ }^{103} I d$. at 618 (Kennedy, J., concurring). 
courts developed. The circuit courts finding that the ADEA allowed disparate impact claims included the Second, Eighth, and Ninth. Courts disallowing such claims were the First, Fifth, Seventh, Tenth, and Eleventh. $^{104}$

In 2002, the Supreme Court granted certiorari to resolve the split, but subsequently dismissed the writ of certiorari as improvidently granted. ${ }^{105}$ Over two years later, the Court again granted certiorari to resolve the split, heard the argument in Smith, and finally laid to rest the confusion Hazen Paper had wrought.

\section{The InTERPlay of Two Presumptions: The Duplicating RAY AND THE ORIGINAL “SUPER” POWER}

This part will provide a more thorough explanation of the practice of and the theory behind the two presumptions that were at play in Smith. First, it discuses the presumption that statutory text that is lifted from one statute into another should result in consistent interpretations of the statutes' shared language. Then, it turns to the presumption of enhanced statutory stare decisis.

\section{A. The Consistency Presumption: Duplicating Prior Interpretations}

When the legislature borrows language from one statute to draft a subsequent statute, courts generally agree that the statutes should be construed consistently with one another. Thus, an interpretation of one statute is usually treated as binding on the other, when it involves the same language. This is a specific application of the in pari materia canon of statutory construction. ${ }^{106}$ For purposes of this paper, I call it the "consistency presumption."

Courts have applied the consistency presumption when interpreting the

${ }^{104}$ See Smith, 544 U.S. at 237 n.9.

${ }^{105}$ Adams v. Florida Power Corp., 535 U.S. 228 (2002).

106 See BLACK's LAW DictionARY 791 (6 ${ }^{\text {th }}$ ed. 1990) (“[S]tatutes which relate to the same subject matter should be read, construed and applied together so that the legislature's intention can be gathered from the whole of the enactments."). See also Caren Spencer, Comment: When a Boss Isn't an Employer: Limitations of Title VII Coverage, 25 BERKELEY J. EMP. \& LAB. L. 441, 466 (2004) ("Analysis of Title VII, the ADA, and ADEA is very closely integrated, as Title VII and ADEA use the same definitions in most instances and many of those terms are explicitly incorporated into the ADA. As the statutes have similar goals and structures, using the canon of in pari materia, they should be interpreted similarly, unless the legislative history or purpose suggests material differences."). 
language of the ADEA that was lifted directly from Title VII. ${ }^{107}$ This presumption was a central theme in the Smith case, not only because it was the "duplicating ray" by which the Court's deference to Wards Cove out of respect for statutory stare decisis was Bizarro, but also because the Court treated Griggs as "precedent of compelling importance." 108 The statutory language at issue in Griggs was nearly identical to that at issue in Smith. ${ }^{109}$

\section{B. Statutory Stare Decisis: The "Super-Strong Presumption"}

The Supreme Court traditionally has been exceedingly deferential to its precedents that involve interpretation of ambiguous statutory language. ${ }^{110}$ William Eskridge dubbed the Court's practice of enhanced statutory stare decisis a "super-strong presumption.""11 According to the doctrine of statutory stare decisis, once the Court has interpreted statutory language, it will avoid revisiting the issue. ${ }^{112}$ The underlying theory is that, unlike the

107 See, e.g., Smith, 544 U.S. at 233-34 ("We have consistently applied that presumption to language in the ADEA that was derived in haec verba from Title VII." (internal quotes omitted)); Western Air Lines, Inc. v. Criswell, 472 U.S. 400, 416 (1985) (using interpretations of Title VII's bona fide occupational qualification defense as authoritative interpretations of the ADEA's identically-worded defense); Trans World Airlines, Inc. v. Thurston, 469 U.S. 111, 121, 83 L. Ed. 2d 523, 105 S. Ct. 613 (1985) ("This interpretation of Title VII of the Civil Rights Act of 1964 applies with equal force in the context of age discrimination, for the substantive provisions of the ADEA were derived in haec verba from Title VII." (internal citation and quotes omitted)).

${ }^{108}$ Smith, 544 U.S. at 234.

${ }^{109}$ In both cases, the language was:

It shall be an unlawful employment practice for an employer . . . to limit, segregate, or classify his employees or applicants for employment in any way which would deprive or tend to deprive any individual of employment opportunities or otherwise adversely affect his status as an employee, because of such individual's

age, 29 U.S.C. $\S 623(a)(2)$ (2000), or race, color, sex, religion or national origin, 42 U.S.C. $\S 2000 \mathrm{e}-2(\mathrm{a})(2)(2000)$,

${ }^{110}$ See Barrett, supra note 9, at 319 (describing the doctrine of statutory stare decisis).

${ }^{111}$ Eskridge, Overruling, supra note 2, at 1363.

112 The Court's most famous and enduring example of adhering to a statutory interpretation of increasingly lessening viability involved Fed. Baseball Club of Balt., Inc. v. Nat'l League of Prof'l Baseball Clubs, 259 U.S. 200 (1922), which granted organized baseball an exception to the Sherman Act's prohibition of contracts in restraint of trade. In two subsequent cases, the Court continued to stand by the Federal Baseball exemption, despite the fact that the Court had refused to provide similar exemptions for the other similar professional sports leagues. See Toolson v. N.Y. Yankees, Inc., 346 U.S. 356 (1953); Flood v. Kuhn, 407 U.S. 258 (1972). The basis for this super-strong presumption of validity for Federal Baseball was that it was a statutory interpretation decision and Congress could have, but did not, override it. See Toolson, 346 U.S. at 357; Flood, 407 U.S. at 258. For a concise but complete discussion of the baseball cases, see Barrett, supra note 9 , at $319-20$. 
constitutional interpretation context where legislative action is a virtual impossibility, ${ }^{113}$ Congress has the ability to - and with relative frequency, in fact, does ${ }^{114}$ - step in to correct and to override the Court's statutory interpretation decisions with which it disagrees. ${ }^{115}$ As a result, a party who requests that the Court overrule a statutory precedent faces a more onerous burden than does a party who requests that the Court revisit other types of cases. $^{116}$ If a change in the interpretation is what the party seeks, Congress is the appropriate body to make such policy choices, if possible.

Rules of stare decisis, including that for enhanced statutory stare decisis are not mandatory, though. Stare decisis is a prudential doctrine. ${ }^{117}$ Thus it can be, and with relative frequency is, ignored and statutory interpretation decisions are overruled by the Court. ${ }^{118}$ If there is some "special justification," the Court may retreat from an earlier statutory precedent. ${ }^{119}$ Amanda L. Tyler, who advocates for a strong (but not absolute) rule of statutory stare decisis, would find such special justification when statutory precedents are "wholly out of sync with the legal fabric.",

${ }^{113}$ Eskridge argues that the strength of the Supreme Court's adherence to stare decisis differs with the kind of case it is deciding. Statutory interpretation precedents receive the super-strong presumption. Constitutional precedents are afforded relatively weak precedential value. Federal common law precedents are more respected than constitutional decisions, but are more likely to be overruled than statutory precedents. See Eskridge, Overruling, supra note 2, at 1362.

${ }^{114}$ For an extensive empirical study of the frequency with which Congress overrides Supreme Court statutory interpretation decisions, see generally Eskridge, Overriding, supra note 2. Eskridge studied the years 1967-1990. Id. at 335. In particular, he determined that each Congress between 1975 and 1990 overrode an average of about a dozen of the Court's statutory interpretation decisions. Id. at 335-36.

${ }^{115}$ See, e.g., Johnson v. Transportation Agency, 480 U.S. 616, 630 n.7 (1987) ("When a court says to a legislature: 'You (or your predecessor) meant $X$,' it almost invites the legislature to answer: 'We did not."'). See also Daniel A. Farber, Statutory Interpretation, Legislative Inaction, and Civil Rights, 87 MICH. L. REV. 2, 13 (1988) ("[I]n general, we can expect more extensive Congressional activity when Congress strongly disapproves of the result.").

${ }^{116}$ See Barrett, supra note 9 at 317.

117 See Farber, supra note 115, at 17 ("Rather than being a domain of tightly constraining rules that preclude consideration of broader public values, stare decisis is a largely prudential doctrine.").

${ }_{118}$ Indeed, Eskridge chronicles more than 80 cases in the period between 1961 and 1986 in which the Supreme Court either explicitly or implicitly overruled its own prior statutory interpretation decisions. See Eskridge, Overruling, supra note 2, at 1368 and Appendixes A and B (1430-39).

119 See Lawrence C. Marshall, "Let Congress Do It”: The Case for an Absolute rule of Statutory Stare Decisis, 88 MICH. L. REV. 177, 179 (1989) (citing Patterson v. McLean Credit Union, 491 U.S. 164, 172 (1989) (quoting Arizona v. Rumsey, 467 U.S. 203, 212 (1984))).

${ }^{120}$ See Amanda L. Tyler, Continuity, Coherence, and the Canons, 99 Nw. U.L. REV. 
Several rationales have been advanced to support the super-strong presumption of statutory stare decisis. The most prominent are described in the following subparts.

\section{Congressional acquiescence}

The most common argument is that of congressional acquiescence, based on Congress's inaction. Acquiescence theory is based on the assumption that Congress's silence, or lack of action in response to the Court's interpretation is tantamount to Congress's endorsement of that interpretation. Thus, the Court has no reason to revisit or overrule its interpretation because Congress has implicitly approved it. ${ }^{121}$ Acquiescence theory is reflected in the language typically found in Supreme Court statutory stare decisis opinions. Indeed, the plain language of Justice Stevens's opinion in Smith reveals that he is relying on congressional silence as an indication of endorsement. ${ }^{122}$

In its simplest form the theory is as follows: We (the Court) interpreted the statute. You (the legislature) did nothing in response. We would expect you to respond if you did not approve; therefore, you approve. ${ }^{123}$ Professor Eskridge explains the persuasive force of the reasoning by elucidating the

1389, 1417-18 (2005). Tyler expounds on what might make a precedent "wholly out of sync, listing "where the precedent failed to apply a consistently-employed canon, cannot be squared with precedents interpreting companion statutory provisions or similarly-worded statutes, or has generated only great confusion (as opposed to clarity) in the law." Id.

${ }^{121}$ For an in depth treatment of the Supreme Court's use of congressional inaction as an interpretive tool, see generally William N. Eskridge, Jr., Interpreting Legislative Inaction, 87 MICH. L. REV. 67 (1988).

${ }_{122}$ Smith v. City of Jackson, 544 U.S. 228, 240 (2005) ("While the relevant 1991 amendments expanded the coverage of Title VII, they did not amend the ADEA or speak to the subject of age discrimination. Hence, Wards Cove's pre-1991 interpretation of Title VII's identical language remains applicable to the ADEA.").

${ }^{123}$ Granted, this is the acquiescence theory at its most simplistic. But, that simplistic logic is what often finds its way into the opinions when the Court trots out statutory stare decisis as a justification for its interpretation. Still, Daniel A. Farber has offered a unique and more sophisticated public choice theory justification to support acquiescence theory, based on the supposed preference of legislators, ex ante, for a rule that would find significance in congressional inaction. Because legislators cannot know at the time of enactment whether subsequent judicial interpretations will be favorable or unfavorable to them - and, assuming good faith efforts by judges to interpret the statutes accurately, one would expect a roughly equal probability of favorable and unfavorable interpretations legislators would prefer a strong statutory stare decisis rule rather than a weak one that will impose costs of uncertainty and unreliability. According to Farber, a legislator will take the bargain of allowing mistaken interpretations to stay on the books for the equally likely possibility that favorable interpretations will have staying power as well. See Farber, supra, note 115, at 11-13. 
metaphor of Waddlington, the principal who tells his agent to buy him "soupmeat," and Krattenmaker, the agent who buys beef in response to the command. If Waddlington says nothing to Krattenmaker to correct him or repudiate his choice of beef soupmeat, as opposed to chicken or pork, then we would presume that Waddlington in fact intends Krattenmaker to continue buying beef. ${ }^{124}$

The theory, though, is flawed because it begs the central question of what meaning should be attached to congressional inaction. Unlike the case of Waddlington and Krattenmaker, often the Congress sitting at the time of the Court's potentially controversial interpretation is different from the originally enacting Congress. ${ }^{125}$ While Waddlington is the same person both when he commanded Krattenmaker to get the soupmeat and when Krattenmaker brings back the beef, Congress is a "discontinuous decisionmaker." Eskridge argues that a subsequent Congress's reaction to a Court's interpretation is not as constitutionally relevant as the intent of the enacting Congress. $^{126}$ Furthermore, Waddlington is motivated to correct Krattenmaker if beef is not what he wanted. He has to eat the beef or go hungry. Congress, on the other hand, is a public decisionmaker. As such Congress, as a collective body, ${ }^{127}$ has little or no "personal" stake in the Court's interpretation. In other words, it does not have to eat the beef served up by the Court's interpretation. Instead, it is forcing the Court's beef onto the public. While the public may prod Congress to react, there are significant obstacles to overcome in that regard. ${ }^{128}$

Acquiescence theory has been roundly criticized and largely dismissed as insufficient to justify the doctrine of enhanced statutory stare decisis. ${ }^{129}$ In particular, Marshall has nicely encapsulated the most practical objections

${ }^{124}$ See Eskridge, Interpreting, supra note 121, at 93.

${ }^{125} \mathrm{Id}$. at 94 .

${ }^{126} \mathrm{Id}$.

${ }^{127}$ Eskridge also notes that Congress as a collective decisionmaker cannot be as easily assigned a single motivating intent for its action or inaction as can Waddlington, a single decisionmaker. Id. ("While Waddlington may sometimes 'be of two minds,' Congress is always of two minds (the House and the Senate) and each of them contains many different minds.").

${ }^{128}$ See, e.g., infra notes 131-132, 202-205 and accompanying text.

129 See, e.g., Johnson v. Transportation Agency, 480 U.S. 616, 672 (Scalia, J., dissenting) (“The 'complicated check on legislation[]' erected by our Constitution creates an inertia that makes it impossible to assert with any degree of assurance that congressional failure to act represents (1) approval of the status quo, as opposed to (2) inability to agree upon how to alter the status quo, (3) unawareness of the status quo, (4) indifference to the status quo, or even (5) political cowardice." (internal citation omitted)); Eskridge, Interpreting, supra note 121, at 95 ("Acquiescence arguments are almost never persuasive indicia of actual legislative intent."). 
into four " $i$ "s: ignorance, ${ }^{130}$ inertia, ${ }^{131}$ interpretational ambiguity, ${ }^{132}$ and irrelevance. $^{133}$ Finally, several commentators have raised constitutional objections to the acquiescence justification, because interpretations become quasi-legislative while circumventing the constitutional legislative process of bicameralism and presentment. ${ }^{134}$

\section{Task-splitting}

While the acquiescence theory seems to provide insubstantial support for the doctrine, enhanced statutory stare decisis is justified on several other theoretical grounds. One vision of the justification is based on proper resource allocation between Congress and the judiciary. Lawrence Marshall

${ }^{130}$ See Marshall, supra note 136, at 186-90 (Congressional ignorance is as likely to lead to inaction as is congressional contemplation and acquiescence). See also Eskridge, Interpreting, supra note 121, at 75 ("One strategy is to show that Congress was not aware of the judicial or administrative interpretation and, therefore, could not be charged with any form of approval by its failure to overturn it.").

131 See Marshall, supra note 119, at 190-91 (Congress is afflicted (by design) with issues of organizational inertia that block or frustrate Congress's ability to pass legislation even when a majority of legislators desire it). See also Eskridge, Interpreting, supra note 121, at 98 ("[T]he structure of Congress makes it far more likely that something will not happen (inaction) than that it will (action)."). Eskridge provides, as an example of this truism, the story of Congress's laborious experience overriding Grove City College v. Bell, 465 U.S. 555 (1984) with the Civil Rights Restoration Act of 1988, Pub. L. No. 100-259, 102 Stat. 28 (1988). Though Grove City never enjoyed the support of committees or the full membership of either house of Congress, overriding it required persevering through four years of legislative roadblocks, including the introduction of several different versions of the bill, a filibuster, and a veto. All the while, a majority of Congress favored overriding Grove City. See Eskridge, Interpreting, supra note 121, at 99 n.181.

132 See Marshall, supra note 119, at 191-93 (serious interpretational ambiguity plagues any attempt to finding meaning in silence and inaction).

133 See id. at 193-96 (in other circumstances, the Court adheres to a rule that treats subsequent legislative history as irrelevant to the meaning and intent of the enacting legislature, so it is odd that this particular post-enactment history (sometimes far removed in time and purpose from the original enactment) should be favored over relatively more contemporaneous and unambiguous post-enactment history). See also Eskridge, Interpreting, supra note 121, at 96 ("The acquiescence . . .cases directly conflict with these propositions [that subsequent legislative statements are not useful because they do not comply with procedural structures for statutory law found in the constitution]. If subsequent legislative statements directly supporting a statutory interpretation are not valid evidence, how can subsequent legislative silence, usually just indirectly supporting a statutory interpretation, be considered any more authoritative?")

${ }^{134}$ U.S. CONST. art. I §7. See also Barrett, supra note 9, at 338-39 (summarizing the constitutional impediments to the acquiescence rationale); Eskridge, Interpreting, supra note 121, at 96; Marshall, supra note 119, at 194 ("Indeed, [acquiescence] is more than silly; it is contrary to fundamental constitutional principles."). 
calls this the "task-splitting" theory or argument. ${ }^{135}$ The task-splitting argument does not rely on interpreting silence and inaction, but simply claims that no great harm is risked when the Court rigidly sticks with its statutory interpretations, because Congress is available and empowered to act if it desires. Thus, the Court's resources are freed up to focus on new issues rather than being tasked with constantly revisiting prior interpretations. ${ }^{136}$ As Marshall points out, though, the task-splitting theory still suffers from problems of ignorance and inertia. ${ }^{137}$ In addition, the mere fact that Congress is available to override erroneous statutory interpretations is not a good reason by itself to allocate the job to it. Congress is also busy and could benefit from having its resources freed for other purposes. Correspondingly, the Court is equally available to take on the task of reevaluating its prior interpretations and overruling the erroneous ones. ${ }^{138}$

\section{Separation of powers}

\section{a. Constitutionally-compelled}

Taking up where task-splitting falls short (i.e., providing more than a pragmatic justification for allocating the job to Congress) is the argument that the Constitution requires the congressional preference based on the separation of powers doctrine. ${ }^{139}$ Justice Hugo Black was the most vocal and ardent supporter of this position on the Supreme Court. ${ }^{140} \mathrm{He}$ argued that once the Court interpreted, by necessity, ambiguous language, that interpretation became like part of the statutory text and the Court would not be at liberty to alter or overrule its interpretation, because that would be akin to a judicial usurpation of a congressional power. Justice Black found little support for his constitutionalized statutory stare decisis approach. In the end, Justice Black's approach is insufficiently supported by constitutional doctrine, ${ }^{141}$ as well as seemingly internally inconsistent. Specifically, Black advanced no coherent explanation for why the Court's first interpretation is treated as statutory text, but subsequent interpretations or modifications would exceed the Court's constitutional authority. ${ }^{142}$

${ }_{135}^{135}$ Marshall, supra note 119, at 197-98.

${ }^{136}$ See id.

${ }^{137} \mathrm{Id}$.

${ }^{138} I d$. at 198.

139 See Barrett, supra note 9, at 325-26, 340-41 (discussing and dismissing this argument).

${ }^{140}$ See Eskridge, Overruling, supra note 2, at 1397-1398.

${ }^{141}$ See Barrett, supra note 9, at 341 (explaining that Justice Black "does not identify the force that transforms an initial judicial interpretation into statutory text").

${ }^{142}$ See id.; Eskridge, Overruling, supra note 2, at 1399 ("The argument's distinction 


\section{b. Norm-based}

Still another justification for strong statutory stare decisis, which is likewise grounded in separation of powers considerations, does not claim that the constitution prohibits overruling statutory precedents. Instead, it uses the values inherent in the separation of powers doctrine to suggest that a heightened rule of statutory stare decisis is a normatively superior, constitutionally-based policy. ${ }^{143}$ According to this approach, the countermajoritarian nature of judicial statutory interpretation suggests that the Supreme Court should avoid it when possible and accept (indeed, perhaps encourage) legislative supremacy with regard to statutory policymaking. Marshall urges the Court to adopt an absolute rule of statutory stare decisis, in order to send the clear signal that Congress - and only Congress - is responsible for fixing any mistakes of judicial interpretation. $^{144}$ If so instructed, the theory is that Congress will be more likely to act definitively and quickly to correct mistakes of judicial statutory interpretation. 145 Congress will no longer have an incentive to "hang back" waiting to see if the Court fixes the mistake, which the Court will do from time to time without an absolute stare decisis rule. ${ }^{146}$ Barrett would not go

between acceptable judicial lawmaking (the original interpretation) and the unacceptable judicial lawmaking (the overruling) is essentially a semantic one, with no persuasive formal justification.").

${ }^{143}$ See Barrett, supra note 9, at 325-26, 340-41, 348 (advocating a heightened statutory stare decisis rule to encourage judicial restraint and to avoid the distrust that accompanies Congress's delegation of policymaking to the federal courts through statutory ambiguity); Marshall, supra note 119, at 200-208 (developing the case for an absolute rule of statutory stare decisis, aimed at creating an incentive for Congress to assume supremacy).

${ }^{144}$ Marshall, supra note 119 , at 211.

${ }^{145}$ Id. ("There should be a marginally higher level of congressional oversight in the system in which courts apply a heightened or absolute rule of statutory stare decisis. For in that system the legislators, lobbyists, and public all know that any changes in the interpretation of statutes can come only through legislative action - not through a judicial reversal of the announced interpretation.")

In this way, Marshall's absolute rule of statutory stare decisis performs a similar function as a preference-eliciting default statutory rule as expounded by Einer Elhauge, albeit much less radically. See Einer Elhauge, Preference-Eliciting Statutory Default Rules, 102 ColuM. L. REV. 2162, 2165(2002) [hereinafter Elhauge, Preference-Eliciting] ("The justification for preference-eliciting canons thus need not rest in their correspondence to either legislative preferences or sound policy. The justification - and necessary predicate - is rather that the default result is more likely to be reconsidered (and deliberated) by the legislature because it burdens some politically powerful group with ready access to the legislative agenda.") Both are focused on disciplining the legislature to enact its true policy preferences. Both are more stick than carrot. Elhauge's stick is just much heavier and sharper.

${ }^{146}$ Marshall, supra note 119, at 213. 
so far as an absolute rule, in part because she does not seek as a primary goal to influence Congress's actions, but instead to cabin the federal courts' exercise of the dubious policymaking powers inherent in statutory interpretation. $^{147}$

\section{Reliance, Continuity, and Coherence}

In two influential articles, Einer Elhauge recently offered a re-imagining of dynamic statutory interpretation theory, ${ }^{148}$ which prompts interpreting courts to estimate the enactable preferences of the current legislature - or, when discovering those preferences proves impossible, to adopt preferenceeliciting interpretations - rather than focusing solely on the original meaning or original purpose of the enacting legislature. By adopting preference-estimating default rules, Elhauge argues that judges are better suited to step into the role of the "faithful agent" to the legislature. ${ }^{149} \mathrm{He}$ argues that judges are thus constrained from implementing their own views, because they must in good faith estimate what enactable preferences the current legislature has. Elhauge sees such enactable preferences only in legislative committee reports or other positive legislative actions, not from judges' own estimation of the polity's preferences. ${ }^{150}$ This is a somewhat restricted role for the judge in comparison to Elhauge's dynamic theory predecessors, who urged judges to consult broad social norms and values to update statutes. Obviously, Elhauge and the other dynamic theorists put little stock in heightened statutory stare decisis. ${ }^{151}$

${ }^{147}$ See Barrett, supra note 9, at 348.

Both Marshall and Barrett recognize that the countermajoritarian problem of judicial creativity inherent in interpreting statutes is, at times, unavoidable. Therefore, they both seek to limit it beyond the initial, unavoidable interpretation of ambiguous language. Marshall, however, also notes that congressional passivity is a problem with statutory interpretation and seeks, with his absolute rule of statutory stare decisis, to shake Congress out of that passive role and to step up as the primary authority on statutory interpretation and legislating. See Marshall, supra note 119, at 207.

Of course, Marshall's proposal is subject to criticism from a number of perspectives. William N. Eskridge, The Case of the Amorous Defendant: Criticizing Absolute Stare Decisis for Statutory Cases, 88 MiCH. L. REV. 2450 (1990) (offering a "Speluncean Explorers" inspired critique of Marshall's proposal from law and economics, structuralist, and critical legal studies viewpoints).

148 See, e.g., Einer Elhauge, Preference-Estimating Statutory Default Rules, 102 Colum. L. ReV. 2027 (2002); Elhauge, Preference-Eliciting, supra note 153.

For a discussion of dynamic statutory interpretation theory, see T. Alexander Aleinikoff, Updating Statutory Interpretation, 87 MicH. L. REV. 20 (1988); William N. Eskridge, Jr., Dynamic Statutory Interpretation, 135 U. Pa. L. Rev. 1479 (1987).

${ }^{149}$ Elhauge, Preference-Estimating, supra note 148, at 2039-40.

${ }^{150} \mathrm{Id}$. at 2107.

${ }^{151}$ Dynamic theorists as a group presumably would not support a strong statutory stare 
Largely in response to Elhauge, Amanda L. Tyler has proposed the most recent defense of a limited judicial role and a strong doctrine of statutory stare decisis. ${ }^{152}$ Her article "promotes as normatively superior the construction of an interpretive regime built on a strong rule of statutory stare decisis and consistent application of interpretive guides that advance continuity and coherence." 153 Continuity, according to Tyler, calls for incremental statutory change by courts and then only when there is some considerable indication that the statutory baseline must be upset. ${ }^{154}$ Coherence is achieved by "reconciling and harmonizing linguistic meaning among numerous interpretations over time." 155 Tyler argues that relying on the legislature to affect legislative change allows stronger reliance interests to build, because it avoids retroactive application that is inherent in most judicial decisions and it will happen with less frequency and more deliberation, because legislative amendment is costlier than judicial "updating" of statutes. ${ }^{156}$

The continuity and coherence values dominating Tyler's approach reflect the continuity policy that Eskridge argues is the basis for all stare decisis. ${ }^{157}$ According to Eskridge, continuity is desirable for three reasons: (1) it is the basis for the legitimacy of law, because we feel more secure in the rule of law when it does not shift with the blowing winds; (2) it protects reliance interests of the public; and (3) it protects the coherence of the law. ${ }^{158}$ Thus, to the extent that a statutory interpretation incorporates these policy goals, it should be respected and protected from tinkering. ${ }^{159}$

decisis rule and, thus, would wholly reject the Court's use of it in Smith. The goal of this paper, however, is not to advocate for one or another among the various interpretative theories. Rather the paper's goal is to illustrate why the Smith Court's application of statutory stare decisis was not really traditional statutory stare decisis at all and to advocate for a recognition that Bizarro statutory stare decisis is problematic and should not be emulated.

152 Tyler builds on the ideas of David Shapiro, among others. See, e.g., David L. Shapiro, Continuity and Change in Statutory Interpretation, 67 N.Y.U.L. REV. 921 (1992).

${ }^{153}$ Tyler, supra note 120 , at 1406.

${ }^{154}$ See id. ("This principle may be understood as viewing statutory change through the lens of incrementalism.") Eskridge refers to this interest as "“vertical continuity,' that is, the perseverance of an interpretation over time." Eskridge, Interpreting, supra note 121, at 70 .

155 Tyler, supra note 120, at 1406. Eskridge refers to this interest as " $h o r i z o n t a l$ continuity,' that is, the coherence of rules and policies at any given time." Eskridge, Interpreting, supra note 121 , at 70.

${ }^{156}$ See id. at 1414. Cf. Eskridge, Interpreting, supra note 121 at 70 (arguing that congressional inaction should be treated as acquiescence to "building block interpretations" by courts, because such interpretations "give[] rise to public or private reliance interests").

${ }^{157}$ Eskridge, Interpreting, supra note 121 at 110.

${ }^{158} \mathrm{Id}$.

159 Eskridge calls interpretations that advance these goals "building block 
It is important to note that Tyler does not advocate an absolute rule of statutory stare decisis and makes room for judicial overruling when an interpretation has been arrived at without the proper concern for consistency or coherence, when an interpretation is inconsistent with a larger statutory scheme, or when the statute has caused confusion rather than coherence. ${ }^{160}$

\section{The SMIth Decision: The Origin OF BiZARro Statutory Stare DECISIS AND WHY IT IS BIZARRO}

\section{A. The Smith Opinion}

The Smith Court determined that the ADEA did in fact include a claim for disparate impact. While it is different from the Title VII claim in significant and important ways, the Court oddly relied on the congressionally overridden interpretation of Title VII in Wards Cove to structure the ADEA impact analysis. ${ }^{161}$ This reliance on Wards Cove is Bizarro statutory stare decisis.

In Smith, a number of police officers aged 40 and over filed a claim of age discrimination against the City of Jackson, Mississippi (the City), alleging that a pay plan the City adopted and revised between October 1998 and May 1999, which granted pay increases to all City employees, discriminated against officers who were over 40 years old. ${ }^{162}$ The plan and its revision were motivated, at least in part, by the City's desire to attract and retain qualified people, reward performance, and, most notably, to bring the starting salaries of police officers in line with comparable positions in the region. ${ }^{163}$ While the plaintiffs claimed that the pay plan was evidence of disparate treatment, the relevant issue to the case was their claim that the pay plan resulted in proportionately greater raises for less senior officers than for those with greater seniority. ${ }^{164}$ This adverse effect for police

interpretations." Id. at 108, 111.

${ }^{160}$ See supra note 120 and accompanying text. Similarly, Eskridge argues that courts' frequent conclusion in applying statutory stare decisis - that legislative inaction in response to an interpretation evinces Congress's intent that the interpretation is correct - overvalues "vertical continuity" (or, in Tyler's parlance, continuity) and undervalues "horizontal continuity" (or coherence). See Eskridge, Interpreting, supra note 121, at 70. Both are important, so one should not be sacrificed routinely in service of the other.

161 Smith v. City of Jackson, 544 U.S. 228, 240 (2005) ("While the relevant 1991 amendments expanded the coverage of Title VII, they did not amend the ADEA or speak to the subject of age discrimination. Hence, Wards Cove's pre-1991 interpretation of Title VII's identical language remains applicable to the ADEA.”).

${ }^{162} I d$. at 231.

${ }^{163} I d$.

${ }^{164} I d$. 
officers who were over 40 years of age - while a few less senior officers were 40 or older, the vast majority of older officers had greater seniority and, thus, proportionately lower raises - formed the basis for their disparate impact claim. ${ }^{165}$

The statistics supported the claim of adverse impact. In particular, twothirds of officers under age 40 received raises greater than $10 \%$, while less than half of officers over 40 years old did. ${ }^{166}$ Second, in terms of average percentage increases, the entire class of officers over 40 years old fared worse than the younger officers. ${ }^{167}$

The District Court granted summary judgment to the City on the plaintiffs' claims and the Fifth Circuit affirmed that decision as to the disparate impact claim, determining that the ADEA did not incorporate disparate impact theory. ${ }^{168}$

The Justices unanimously agreed that the grant of summary judgment to the City on the disparate impact claim was appropriate. Five justices agreed that the ADEA incorporated a limited form of disparate impact theory; however, Justice Scalia filed a concurring opinion explaining how his reasoning differed slightly from the plurality of the other four. The three remaining justices ${ }^{169}$ disagreed with the majority, concluding that disparate impact claims should not be available under the ADEA.

Justice Stevens's opinion (which announced the judgment of the Court and was, in all but one part, the majority opinion) relied on three complementary lines of reasoning. First, citing the consistency presumption, he focused on the similarity of the operative language of Title VII and the ADEA. ${ }^{170}$ Second, he analyzed the specific language of the ADEA, particularly the RFOA provision, and determined it also supported the contention that the ADEA incorporated disparate impact. ${ }^{171}$ Third, he concluded that the court should defer to the agency interpretations that were on point. Specifically, he noted that "the Department of Labor . . . and the EEOC . . . have consistently interpreted the ADEA to authorize relief on a disparate-impact theory." 172 Justice Scalia declined to join the plurality in the section of Justice Stevens's opinion focusing on the legislative text and intent. Although he "agree[d] with all of the Court's reasoning" in that part, he did not believe it was necessary as an "independent determination of the

${ }^{165} I d$. at 242 .

${ }^{166} \mathrm{Id}$.

${ }^{167} I d$.

${ }^{168}$ Id. at 231 .

${ }^{169}$ Chief Justice Rehnquist took no part in the consideration or decision of the case. Id. at 243 .

${ }^{170} I d$. at $233-34$

${ }^{171} I d$. at $238-39$.

${ }^{172}$ Id. at 239. 
disparate impact question," instead preferring to use it as a reason to apply Chevron deference to the EEOC's interpretation of the ADEA. ${ }^{173}$

Justice O'Connor disagreed both with the majority's reading of the statute and with Justice Scalia's deference to the EEOC. She found that the "reasonable factor other than age" defense in the ADEA ${ }^{174}$ (not present, of course, in Title VII) makes Griggs wholly inapplicable to the ADEA; ${ }^{175}$ that the legislative history of the ADEA made clear that the policy underlying disparate impact claims was missing from the ADEA; ${ }^{176}$ and that the Department of Labor and the EEOC were neither consistent in their interpretation of the ADEA nor due deference for the interpretation that Justice Scalia credited, regardless of that inconsistency. ${ }^{177}$

The opinion of the court is important on two bases. First, it resolved the split among the circuit courts. ${ }^{178}$ Second, and more relevant to this paper, the opinion elucidates the proof structure for ADEA disparate impact claims. It is in this portion of the opinion that the Court's reasoning takes the Bizarro turn of relying on Wards Cove despite Congress's clear repudiation of the case.

The way is more difficult for an ADEA plaintiff who wants to use the disparate impact theory. There are two major hurdles. The first hurdle springs from the notable original ${ }^{179}$ textual difference between Title VII and the ADEA, namely, the "reasonable factor other than age" (RFOA) language in $\S 4(\mathrm{f})(1)$ of the ADEA. ${ }^{180}$ For Justices O'Connor, Kennedy, and Thomas, this textual difference was dispositive of the threshold question of whether the ADEA includes a disparate-impact claim. For the majority, the RFOA provision, instead, "plays its principal role by precluding liability if the adverse impact was attributable to a nonage factor that was "reasonable."'181 Rather than saddling the defendant with the

${ }^{173} I d$. at 243 (Scalia, J., concurring in part and concurring in the judgment) (citing Chevron U.S.A. Inc. v. Natural Resources Defense Council, Inc., 467 U.S. 837 (1984)).

${ }^{174} 29$ U.S.C. § 623(f)(1) (2000) ("It shall not be unlawful for an employer . . to take any action otherwise prohibited under subsections (a), (b), (c), or (e) of this section ... where the differentiation is based on reasonable factors other than age. ...").

${ }_{175}$ Smith, 544 U.S. at 251-52 (O’Connor, J. concurring in the judgment).

${ }^{176} \mathrm{Id}$. at $253-54$

${ }^{177} I d$. at 264-65.

${ }^{178}$ See supra notes 55 and 96 and accompanying text..

179 I call it "original" because it was a difference between the ADEA and Title VII from the ADEA's initial passage (i.e., the RFOA clause has always been part of the ADEA and Title VII has never had a analogous provision) and because I mean to draw a contrast between this long-standing difference between the two statutes and the more recent textual difference brought about by the 1991 Act's amendment to Title VII. See supra note 88.

18029 U.S.C. $\S 623(f)(1)$. For the relevant statutory text of this section see supra note 175.

${ }^{181}$ Smith, 544 U.S. at 239. 
burden of proving the "business necessity" defense to escape liability as in Title VII disparate impact claims, the ADEA provides defendants with a safe harbor from liability when it utilizes some reasonable factor other than age, even if that factor results in an adverse impact on older workers. ${ }^{182}$ Obviously, what is reasonable need not always be necessary for the business's operation and, therefore, employers are given a much wider berth under the ADEA. The Smith plaintiffs' disparate-impact claim failed to clear this hurdle. The Court found that the City's reliance on seniority and rank in allocating the pay raises was "unquestionably reasonable given the City's goal of raising employees' salaries to match those in surrounding communities." 183

The second (and more relevant to this discussion) hurdle was that the Court's pre-1991 Title VII disparate impact decisions would govern ADEA disparate impact claims. In particular, the Court relied on Wards Cove. ${ }^{184}$ Relying on Bizarro statutory stare decisis, it imported the requirement that the plaintiff must "isolate[] and identify[] the specific employment practices that are allegedly responsible for any observed statistical disparities." 185 The Court noted that the police officer plaintiffs in Smith failed to isolate the particular practice that led to the disparity in salary increases. In addition, the Court incorporated Wards Cove's requirement that the burden of proof remains at all times with the plaintiff, requiring only a burden of production from the employer in defense. ${ }^{186}$ Although Justice Stevens's opinion for the court did not directly address this issue, he does appear to have treated the plaintiffs as though it was their burden to prove that the criteria of rank and seniority were unreasonable, rather than forcing the City to prove that the criteria were reasonable. ${ }^{187}$ Justice

182 This is because there are so many criteria that employers might legitimately rely on when making employment decisions that are often related to age, unlike the assumptions in Title VII regarding race and sex. $I d$. at 240.

${ }^{183}$ Id. at 242.

184 Smith, 544 U.S. at 240 ("While the relevant 1991 amendments expanded the coverage of Title VII, they did not amend the ADEA or speak to the subject of age discrimination. Hence, Wards Cove's pre-1991 interpretation of Title VII's identical language remains applicable to the ADEA.").

${ }^{185}$ Wards Cove Packing Co. v. Atonio, 490 U.S. 642, 656 (1989) (emphasis added) (quoting Watson v. Fort Worth Bank \& Trust, 487 U.S. 977, 994 (1988)).

${ }^{186}$ Id. 490 U.S. at 659-60.

187 Smith, 544 U.S. at 242. This is an odd circumstance given the fairly plain textual implication of the RFOA is that it acts as an affirmative defense. See 29 U.S.C. 623(f)(1) (2000) ("It shall not be unlawful for an employer . . . to take any action otherwise prohibited under subsections (a), (b), (c), or (e) of this section . . . where the differentiation is based on reasonable factors other than age. ..."). See also Meacham v. Knolls Atomic Power Lab., Docket Nos. 02-7378-cv(L), 02-7474-cv(XAP), 2006 U.S. App. LEXIS 20941 at*39-*47 (2d Cir. Aug. 14, 2006) (Pooler, J., dissenting) (arguing that the RFOA should 
O'Connor's opinion makes clear that she believes that the burden of persuasion stays at all times with the employee, even as the case turns to the RFOA defense. ${ }^{188}$

This is particularly striking because Justice Stevens's opinion employs the language of statutory stare decisis in applying Wards Cove to the ADEA, relying on the fact that the 1991 Act did not change the language of the ADEA which was the identical language at issue in Wards Cove under Title VII. ${ }^{189}$ As previously discussed, relying on congressional silence is prototypical statutory stare decisis reasoning. ${ }^{190}$ However, as discussed below, Congress was hardly silent and this is hardly the prototypical application of the doctrine of statutory stare decisis. The next section describes why Smith's invocation of the doctrine distorts and mutates it, creating the Bizarro version.

\section{B. The Bizarro Nature of Smith's Reasoning (or Lack Thereof)}

Having described the various theories that may be employed, with varying levels of persuasiveness, to justify a doctrine of strong statutory stare decisis, this section now turns to evaluating whether the Smith Court's invocation of the doctrine, which I have called "Bizarro," can be supported by any of them. At the outset it is important to recall that Smith was not a run-of-the-mill case for the application of statutory stare decisis. A typical statutory stare decisis case involves a previously-announced interpretation of the statutory language at issue and no official, final congressional response to that interpretation. Both of those ordinary characteristics are missing in Smith. The statutory language at issue had been previously interpreted, but under Title VII, not the ADEA. ${ }^{191}$ More importantly,

be treated as an affirmative defense based on the plain language of the statute and two canons of statutory construction); Transcript of Oral Argument at 3-6, Smith, 544 U.S. 228 (No. 03-1160) (Justices Stevens, Breyer, and Ginsburg each assume or suggest that the RFOA is an affirmative defense), available at http://www.supremecourtus.gov/ oral_arguments/argument_transcripts/03-1160.pdf.

${ }^{1} 88$ Smith, 544 U.S. $2 \overline{6} 7$ (" $[\mathrm{O}]$ nce the employer has produced evidence that its action was based on a reasonable nonage factor, the plaintiff bears the burden of disproving this assertion.").

${ }^{189} I d$. at 240 ("While the relevant 1991 amendments expanded the coverage of Title VII, they did not amend the ADEA or speak to the subject of age discrimination. Hence, Wards Cove's pre-1991 interpretation of Title VII's identical language remains applicable to the ADEA.").

${ }^{190}$ See supra Part II.B.1 and infra Part III.B.1.

${ }^{191}$ While the Court was absolutely correct that the identical language in Title VII and the ADEA have been traditionally interpreted consistently, see Smith v. City of Jackson, 544 U.S. 228, 233-234 (2005), it is telling that the language at issue in Smith and to which Wards Cove was applied, was not altogether the same as Title VII. Notably, the RFOA 
Congress had been anything but silent and inactive in the intervening time. In the very Title VII context with which Wards Cove dealt, and with specific reference to overriding Wards Cove, ${ }^{192}$ Congress amended Title VII to repudiate the crabbed interpretation of the disparate impact burdens and defenses in Wards Cove.

These unique aspects of the Smith case in terms of the application of statutory stare decisis to Wards Cove are the origins of the Bizarro nature of the statutory stare decisis ultimately brought to life in Smith. The altered circumstances portend the origin of the "imperfect duplicate." For now, I will not dwell any more on these unique aspects of Smith's procedural and substantive quirks, other than to note that each is relevant to showing why a number of the justifications for strong statutory stare decisis are inapplicable to Smith.

Though Justice Stevens seemed to rely on the acquiescence theory, ${ }^{193}$ the following sections will discuss not only whether the acquiescence theory supports the application of statutory stare decisis to Wards Cove but also the several other justifications discussed in section II.B above.

\section{Congressional Acquiescence}

Stevens suggested that Congress had been inactive in response to Wards Cove as regards the ADEA. ${ }^{194}$ That is true enough. The 1991 Act amended only Title VII with regard to the disparate impact theory. Congress took no steps to amend the ADEA's comparable $\S 4(\mathrm{a})(2) .{ }^{195}$ But to say that Wards Cove was met with congressional inaction would be a gross misstatement. Congress "loudly" and definitively wiped out Wards Cove's primary holding. The 1991 Act specifically referenced to, disapproved of, and overrode Wards Cove. ${ }^{196}$ As with any claim of acquiescence, it is difficult

provision, 29 U.S.C. $§ 623(\mathrm{f})(1)$ (2000), was a significant textual difference between the ADEA and Title VII even prior to the 1991 Act's amendments to Title VII. The Court should have recognized that the "limit, segregate, or classify" language of $\S 4(\mathrm{a})(2), 29$ U.S.C. § 623(a)(2) (2000), which is identical to Title VII's pre-1991 language in $\S$ 703(a)(2), gained its meaning, in part, by reference to the textually different $\S 4(f)(1)$ RFOA language. See Smith, 1125 S.Ct. at 1544-45 (2005). Rather than reading $\S \S 4(a)(2)$ and 4(f)(1) together to determine if the RFOA defense might mitigate some of the concerns that animated Wards Cove, the Court simply applied Wards Cove's reasoning.

${ }^{192}$ See supra note 89.

193 See Smith, 544 U.S. at 240 ("While the relevant 1991 amendments expanded the coverage of Title VII, they did not amend the ADEA or speak to the subject of age discrimination. Hence, Wards Cove's pre-1991 interpretation of Title VII's identical language remains applicable to the ADEA.").

${ }_{194}$ See id.

19529 U.S.C. $\S 623(\mathrm{a})(2)$.

196 Professor Howard Eglit calls an argument similar to this "too simplistic to be 
to know what signal to draw from that "silence" and "inaction" of Congress, ${ }^{197}$ especially in light of the conspicuous and active response in repudiating the Court's logic and construction in Wards Cove. ${ }^{198}$

satisfactory." See Howard Eglit, The Age Discrimination in Employment Act, Title VII, and the Civil Rights Act of 1991: Three Acts and a Dog that Didn't Bark, 39 WAYNE L. REV. 1093, 1175 (1993). Though the argument is simple, it is not simplistic. The argument is, in fact, quite powerful. It strains credulity to suggest that Congress should have to comprehensively overhaul the federal code each time it overrides a statutory interpretation. To the extent that the Court's interpretation of statutory language and congress's override of that interpretation is a conversation between coequal branches of government, it is unreasonable for the Court to ignore the clear message of Congress that the prior interpretation of the same or similar language was simply wrong.

Professor Eglit also reads much into the 1991 Act's response to Martin v. Wilks, 490 U.S. 755, 761 (1989) (allowing a post-order challenge to a consent degree under Title VII, even though the challenger had adequate notice that its interests were implicated at the time of the entry of the decree). He argues that Congress's response to Martin, in which it crafted an amendment applying to all federal equal employment opportunity statutes, shows that Congress did amend the ADEA when it was specifically concerned with an interpretation's affect on the ADEA. See Eglit, supra, at 1118. In contrast, he argues, the lack of amendment to the ADEA in response to Wards Cove is significant. The comparison, however, is inapt. Martin was not a case involving the interpretation of a specific section of Title VII. It involved "a principle of general application in AngloAmerican jurisprudence that one is not bound by a judgment in personam in a litigation in which he is not designated as a party or to which he has not been made a party by service of process." Martin, 490 U.S. at 762 (quoting Hansberry v. Lee, 311 U.S. 32, 40 (1940) (internal quotes omitted)). Such a general principle, by its nature, had application in many contexts. And, because Martin did not involve the direct interpretation of statutory language but rather dealt with a general principle of the administration of courts' decisionmaking powers, simply overriding the holding in Martin by amending Title VII would not indicate anything more than that the general principle should not apply to Title VII. Therefore, when Congress acted to "undo" the damage done by Martin, it could not simply amend Title VII as a signal that the Court's reasoning was incorrect. It had to send the message that the procedural rule was inapplicable in all civil rights laws. In such a case, it makes sense to expect Congress to define all the contexts in which that procedural rule does not apply. By contrast, when the Court misinterprets the language of a specific statute, as it did to Title VII in Wards Cove, it should be enough to send the message that the interpretation was wrong by "undoing" that particular interpretation. At the very least, it should be a signal to the Court that the interpretation was disfavored and should not be lightly reapplied elsewhere.

${ }^{197}$ See supra note 132 and accompanying text.

${ }^{198}$ Indeed Eskridge notes that a sometimes successful argument that overcomes the acquiescence theory is "that Congress, even though it has not formally overruled the . . . judicial interpretation, has acted as though the interpretation were not the settled one." Eskridge, Interpreting, supra note121, at 76. This argument grows in strength in the context of Smith. Congress has not just "acted" as though Wards Cove were not a settled interpretation, it actively overrode it. Thus, the opinion relied on an overestimation of the power of the consistency presumption to overcome this objection, which is odd given the Court's care not to overstate the consistency presumption with regard to the main question (i.e., the application of Griggs to the ADEA). Not just relying on the consistency 
To expand Professor Eskridge's Waddlington and Krattenmaker metaphor ${ }^{199}$ to match the situation in Smith, let us assume that Waddlington asked Krattenmaker to fetch him some "soupmeat" for his dinner. However, when Krattenmaker returned with beef, Waddlington rebuffed Krattenmaker by saying, "I cannot stomach beef for dinner. I wanted chicken." If Waddlington had also tasked Krattenmaker to fetch "soupmeat" for the next day's lunch, we would think Krattenmaker foolish simply to assume that Waddlington had intended him to bring back beef for lunch, despite that Waddlington's rebuff only specifically addressed dinner. Given Waddlington's rejection of beef for one meal, we would expect Krattenmaker to seek some sort of clarification regarding the next day's lunch. Moreover, without a specific instruction from Waddlington to Krattenmaker to buy beef, we would likely think it reasonable for Krattenmaker to avoid buying Waddlington any beef at all. Nevertheless, in Smith, the Court played the role of the foolish Krattenmaker, assuming that the Wards Cove "beef" was still Congress's "soupmeat" of choice for the ADEA's "lunch," even though it was resoundingly rejected for Title VII's "dinner."

In addition to the weakness of the Smith Court's reliance on acquiescence as illustrated by the foregoing metaphor, the other critiques of acquiescence theory reveal problems with the revival of Wards Cove.

\section{a. Marshall's four “i”s}

Marshall's four "i"s, ${ }^{200}$ which are fairly devastating critiques of the acquiescence theory, are instructive here. Congress was certainly not ignorant of Wards Cove. To the contrary it was acutely aware of the Court's interpretation of $\S 703(a)(2)^{201}$ of Title VII as shown by the 1991 Act's repudiation of the holding. On the other hand, Congress was ignorant of the fact that the Court would employ this Bizarro form of statutory stare decisis and apply Wards Cove to the ADEA. Thus, it may not have been motivated to try to amend the ADEA.

The critique called "inertia," though likely a misnomer in this instance, provides a much stronger critique. Inertia generally refers to the organizational difficulties (structural, political, and constitutional) facing any congressional attempt to legislate. Overriding a statutory interpretation

presumption to apply Griggs, the Court also sought support from the EEOC interpretations and other textual cues. See Smith, 544 U.S. at 240.

199 See supra notes 125-28 and accompanying text

${ }^{200}$ See supra notes 130-33 and accompanying text.

20142 U.S.C. $\S 2000 \mathrm{e}-2(\mathrm{a})(2)(2000)$. 
is costly. ${ }^{202}$ In the run-of-the-mill case, the inertia problem involves overcoming barriers to developing the sufficient interest, a sense of priority, and will; assembling a coalition of interested legislators and stakeholders; and undertaking the "painstaking deliberation over whether the decision undermines [Congress's] policies and whether alternatives are desirable.",203 To be sure, in the case of Wards Cove and the 1991 Act, Congress mustered the will and energy to overcome the inertia problem and amend Title VII. A critic may ask why, once the "ball was rolling," Congress did not also amend the ADEA's identical language and why the fact that it did not, despite the success of amending Title VII, should not be treated as particularly instructive. But, this criticism misapprehends the costs associated with the inertia problem. Legislating is a delicate balance and putting together too broad an agenda or tackling more than necessary can be lethal to a legislative undertaking. Congress accomplished the main goal in response to Wards Cove: it directly and clearly repudiated the holding in the very context and for the very language that the Court interpreted. That says something instructive about Congress's disapproval of Wards Cove. To expect Congress to venture outside the particular statute Wards Cove interpreted and to expect an amendment insuring against its application in every statute that incorporates a disparate impact claim asks too much.

Eskridge's research regarding the efficacy of the interest groups to affect legislative change is also relevant here. His study indicates that only where the interests of an influential and organized group have been implicated by the interpretation in question does Congress tend to override a judicial interpretation. When groups are scattered or not particularly wellliked, they typically fail to grab Congress's attention. ${ }^{204}$ Typically, older workers would fall into the former rather than the latter category; yet, while older workers are not diffuse or unpopular, they had no immediate vested interest in seeing the ADEA amended in response to a Title VII interpretation that was so clearly repudiated by Congress. ${ }^{205}$

202 See Eskridge, Overriding, supra note 2, at 335-339.

${ }^{203}$ Id. at 339.

${ }^{204}$ Id. at 360 .

${ }^{205}$ But see Harold S. Lewis, Jr., Walking the Walk of Plain Text: The Supreme Court's Markedly More Solicitous Treatment of Title VII Following The Civil Rights Act of 1991, 49 ST. Louis L.J. 1081, 1088 ("In one respect, it is true, the 1991 Amendments shored up Title VII only weakly. In addressing the Court's 1989 decision in Wards Cove Packing Co., Inc. v. Atonio, Congress restored the Title VII disproportionate adverse impact proof mode ... far more tepidly and ambiguously than" in other sections.).

Still, the intent of Congress was clear: to undo what Wards Cove had done.

$[\mathrm{I}] \mathrm{n}$ the interpretive memorandum (which it purported to tell the courts was their sole legitimate guide to any legislative history related to Wards Cove), that the job relatedness and business necessity defenses an employer must use to justify the disproportionate adverse effects of a neutral practice mean that the Supreme Court 
Interpretional ambiguity refers to the fact that Congress may not act or may remain silent in response to a statutory interpretation for a number of reasons $^{206}$ and only one (and perhaps an unlikely one, especially in this instance) is that Congress approves. Indeed, several commentators have suggested several different reasons for Congress's failure to address the ADEA in light of Wards Cove, including (1) that Congress saw no reason to amend the ADEA in response to a Title VII decision ${ }^{207}$; (2) that Congress did not consider how the ADEA might be affected by an interpretation of Title VII and a resulting non-parallel amendment ${ }^{208}$; or (3) that Congress did in fact expect that the 1991 Act's amendments to Title VII would apply to similar statutes like the ADEA, even if those other statutes were not amended. $^{209}$ Therefore, the silence should be scoured for relevant clues to clear up the ambiguity. There are plenty of indicators here that Congress sought to repudiate Wards Cove definitively and would not expect it to crop up again in the ADEA context. Because Congress will almost never override a decision with which it agrees, it seems odd to treat Wards Cove a as though it were any other Court precedent. To do so, seems to suggest another "i": Supreme Court intransigence. ${ }^{210}$

had said such defenses meant in its decisions before Wards Cove.

See id. at 1088-89. So, Congress sought to wipe Wards Cove from our collective memories. The Smith Court ensured that did not happen.

206 See supra notes 127-29 and accompanying text.

207 See Eglit, supra note 196, at 1174-75. Ultimately, although Professor Eglit argues that Wards Cove should apply in the ADEA context, the basis for that conclusion is weaker than it appears at first glance. He states Title VII decisions have "potent analogical force" for interpreting the ADEA. Id. at 1215. See also id. at $1183 \mathrm{n} .303$. That is a much lesser claim than that Wards Cove must apply to the ADEA. Of special note in this regard, is the fact that the decision that warranted a much stronger claim of "potent analogical force" to the ADEA (namely, Griggs, which has never been questioned by Congress, but was in fact endorsed in the 1991 Act) warranted extensive discussion in Smith as to whether it should apply. Thus, it is quite odd that the far weaker claim of analogical force that applies to Wards Cove would warrant almost no discussion. See Smith, 544 U.S. at 240. That is especially true in light of the differences between the ADEA and Title VII, which are quite relevant to the concerns addressed in Wards Cove. See infra Part V.

${ }^{208}$ Eglit, supra note 196, 1168-70.

209 BARbARA T. LindemanN \& DAVID D. KADUE, AgE Discrimination IN EMPLOYMENT LAW 4, 421 (2003) (noting that a committee report from the House Judiciary Committee stated that the laws that were based on the Title VII framework and language, like the ADEA, should be interpreted consistently with Title VII's post-1991 Act amended language; however, this report was not part of the Senate Bill that was ultimately adopted as the 1991 Act.).

${ }^{210}$ One can almost imagine the Justices saying, "Ha! You didn't like Wards Cove, but we thought it was the correct interpretation. So, even though you immediately obliterated it, we're going to keep using it until you tell us we can't!" $C f$. Schnapper, supra note 62at 1100 ("No one but an incorrigible judicial recidivist would consider instead applying to [the 1991 Act and eight other corrective statutes where Congress overrode Court 
The general irrelevance of post-enactment legislative pronouncements, though typically sound, lacks bite in this instance. This is not your everyday post-enactment activity. Congress has tipped its hand to a fairly clear policy decision that the interests and concerns that supposedly underlie Wards Cover are unworthy of credence. In conjunction with the other "i"s, the irrelevance concern actually raises important criticisms of Bizarro statutory stare decisis.

\section{b. Constitutional concerns}

The article I concerns underlying the acquiescence theory also loom large in the Smith case. ${ }^{211}$ The will of Congress to repudiate Wards Cove, as embodied in the 1991 Act, survived a bicameral vote and the presentment process. It was not vetoed. It has been enacted. The Smith court ostensibly decided to treat Wards Cove - a statutory interpretation that was repudiated by Congress and such repudiation was endorsed by the President's signature on the 1991 Act - as a legally binding precedent because Congress did not specifically say it should not be. That directly implicates the concerns (i.e., Congress's avoidance of the article I legislation and policymaking requirements) that Barrett, Marshall, and Eskridge raise. ${ }^{212}$ In effect, it elevates the interpretation of the unelected judges over Congress's expressed will.

Congressional "silence" and "inaction" in the context of the ADEA in response to Wards Cove is simply too flimsy a tool to resurrect Wards Cove after the 1991 Act so clearly put it to rest.

\section{Task-splitting}

The task-splitting justification seems quite inapt in the case of Smith. To the extent that a task was allocated to Congress, it carried that task out in response to Wards Cove. It overrode Wards Cove as regards Title VII,

interpretations] the very defective interpretive methodology that the Congress condemned in enacting those corrective laws. The lessons to be learned from these nine statutes, and from the sixteen short-lived decisions they overturned [including Wards Cove], are not limited to the particular provisions misinterpreted and then amended or to civil rights."). In fairness, this characterization of intransigence is not only a bit intemperate, but also probably excessive, because Justice Stevens, who wrote the opinion adopting the Wards Cove standards in Smith, filed a strong dissent in Wards Cove itself. See Wards Cove Packing Co. v. Atonio, 490 U.S. 642, 662-679 (Stevens, J., dissenting). It is doubtful he relished the opportunity to resurrect unfair. He does, however, have a pattern of strong deference to precedent.

${ }^{211}$ See supra note 134 and accompanying text.

${ }^{212}$ See id. 
making clear in the legislative history that the 1991 Act's amendments were expected to set disparate impact law back to pre-Wards Cove settings. ${ }^{213}$ In addition, the issue of inertia (or, more aptly for this situation, the institutional, structural, and political roadblocks that face a congressional attempt to override a statutory precedent) discussed above plagues the tasksplitting justification as much as the acquiescence theory. The task that Bizarro statutory stare decisis allocates to Congress is onerous. Furthermore, It requires congressional conjecture and encourages tinkering with statutes. It seems much more efficient to treat the situation as one involving an interpretation of first impression, allocating to the Court the work of interpreting any ambiguity, just as it typically would, and allocating to Congress the job of monitoring the correctness of that interpretation. Indeed, it would be odd to justify Smith's invocation of statutory stare decisis on a task-splitting argument, because Bizarro statutory stare decisis potentially creates more work for both branches.

\section{Separation of powers}

Because the Constitution-based separation of powers justification for strong statutory stare decisis has never gained much support beyond Justice Hugo Black and because it is subject to a set of fairly devastating critiques, ${ }^{214}$ it will not be addressed here. It does not provide an independent justification for treating Wards Cove as vaunted precedent.

If the goal of statutory stare decisis is to reflect the values embodied in the separation of powers doctrine, then the application of the strong statutory stare decisis rule to Wards Cove in Smith fails on that count. Marshall's conception is that the strong stare decisis rule will act as a spur to Congress to override precedents it dislikes. ${ }^{215}$ Here that is exactly what happened. It's not clear that the next step of requiring Congress to head off the possibility of that interpretation being applied in every related context should be required to fulfill Marshall's goals under even the absolute rule of statutory stare decisis he advocates. Barrett's judicial restraint justification $^{216}$ does little more to support the application of Wards Cove to the ADEA. The alternative to Bizarro statutory stare decisis ${ }^{217}$ does not undermine Barrett's preference for judicial restraint. It would require the Court to do the work of interpretation, not re-interpretation of a settled issue. In Smith, that would likely result in the Court recognizing the

\footnotetext{
${ }^{213}$ See supra note 89 and accompanying text.

${ }^{214}$ See supra notes 140-42 and accompanying text.

215 See supra notes 144-46 and accompanying text.

216 See supra note 147 and accompanying text.

217 See infra Part V.
} 
differences between the concerns in Wards Cove and the structure of the ADEA, especially in light of the RFOA defense. ${ }^{218}$ That is not judicial activism or illegitimate judicial policy making at its worst. For the Court to resurrect a repudiated and overridden precedent is likely just as activist (if not more) and in need of restraint.

\section{Reliance, continuity, and coherence}

Tyler claims that a strong doctrine of stare decisis supports reliance interests by creating a sense of continuity and coherence in the statutory legal landscape. ${ }^{219}$ In terms of reliance, there was but little reliance on anything related to the disparate impact claim under the ADEA. ${ }^{220}$ After a decade of uncertainty following the Hazen Paper case and following the dismissal of the Adams certiorari petition as improvidently granted, ${ }^{221}$ parties relied on anything related to the ADEA and disparate impact at their own risk. The law was too unsettled and fractured to induce any reasonable reliance. Wards Cove was no "building block interpretation" upon which the public or private parties had grown to rely in ordering their affairs under the ADEA. ${ }^{222}$ Eskridge describes three characteristics of building block interpretations. ${ }^{223}$ Wards Cove had none of them. That Congress overrode Wards Cove is enough to undermine its authority. That the circuits were split regarding whether disparate impact was even available under the ADEA undermines any claims that Wards Cove was either well-settled or induced reliance. ${ }^{224}$ There is no evidence that Congress or any agency, like the EEOC, acted in reliance on Wards Cove applying to ADEA disparate impact cases when developing additional legislation or rules.

In terms of Tyler's conceptions of continuity and coherence, the revival of a definitively overridden interpretation does more violence to continuity

${ }^{218}$ See id.

${ }^{219}$ See supra notes 152-60 and accompanying text.

${ }^{220}$ See supra Part I.B.2.

${ }^{221}$ See supra note 105 and accompanying text.

222 Professor Eskridge contends that reliance interests support a presumption of correctness for "building block interpretations." Building block interpretations are those that are "authoritative, well-settled interpretations upon which public and/or private parties reasonably rely to carry out their roles under the statute." Eskridge, Interpreting, supra note 121 , at 108 .

${ }^{223} I d$. at 111 (the three characteristics are that the interpretation is "authoritative and settled" and "set[s] a firm direction for the statute's development"; that the interpretation has led to reliance by parties who are subject to the statute; and that the interpretation is one upon which Congress or other lawmakers have relied when crafting additional related legal rules).

${ }^{224}$ Nevertheless, some courts that found the ADEA included disparate impact claims prior to Smith also assumed that Wards Cove applied. 
and coherence than heightened statutory stare decisis does to support it. In fact, according to Tyler's own model, certain circumstances warrant deviation from a strong commitment to statutory stare decisis. ${ }^{225}$ In particular, applying Wards Cove in Smith did not show the proper concern for consistency or coherence, it is inconsistent with both Title VII's and the ADEA's statutory schemes, and Wards Cove caused confusion rather than coherence. $^{226}$

\section{The LONG-Term IMPACT OF BizARro Statutory Stare Decisis: BIZARRO GOES EXPLORING}

None of the justifications for heightened statutory stare decisis supports the Smith Court's Bizarro version. If Smith, though, were an anomaly, we could simply dismiss it as a poorly reasoned, but limited, decision. Bizarro statutory stare decisis is not so limited, however. It has been loosed and could turn up in a number of contexts. If so, its effects would be far from positive.

\section{A. The Effects of Bizarro Statutory Stare Decisis: A Shift in the Balance of Power}

Bizarro statutory stare decisis raises significant concerns, most especially by placing an impracticable burden on Congress and by altering the balance of lawmaking power between Congress and the Court. First, if the Court were to routinely invoke Bizarro statutory stare decisis as it did in Smith, Congress would bear the burden of identifying every possible statute to which a disfavored statutory interpretation of the Court might be extended. Because the Court hears so few cases, its statutory interpretations (especially those involving theories of recovery or allocations of burdens) are used as benchmarks or models in a number of other statutory contexts. Indeed the Title VII disparate impact doctrine has been applied to several other statutes. $^{227}$ Were Smith's Bizarro statutory stare decisis to be generally accepted, Congress would be hard pressed to repudiate definitively and override an interpretation by the Court. To do so would require Congress to canvass the entire statutory landscape for potential statutes to which the Court might extend the interpretation that meets with

${ }^{225}$ See supra note 160 and accompanying text.

${ }^{226} I d$.

${ }^{227}$ See Eglit, supra note 196, at 1150 n.200 (collecting cases illustrating other contexts in which Title VII disparate impact has been used as a model or guide, including the Equal Credit Opportunity Act, Title VIII of the Civil Rights Act of 1964, and numerous state statutes). 
congressional disapproval. That is impractical and unworkable. ${ }^{228}$ When Congress kills an interpretation, it should be able to presume that the Court will not resurrect that interpretation without some particularly compelling indication that the interpretation is warranted with regard to the related statute.

Furthermore, Bizarro statutory stare decisis shifts the balance of power toward Court and away from Congress, in effect making Congress a reactive body to the Court's policymaking. That state of affairs raises serious countermajoritarian concerns. ${ }^{229}$

So what?

If Smith were just an isolated mistake, then the effort to criticize it might be nothing more than futile pedantry. But, Smith is no anomaly. Even if we limit our inquiry to the Title VII/ADEA interaction, the 1991 Act overrode a number of Supreme Court interpretations by amending Title VII. As with Wards Cove, Congress did not typically amend the ADEA as well. $^{230}$ Thus, Bizarro statutory stare decisis can, and likely will, be a menace in other contexts. The following section provides one such example. $^{231}$

\section{B. An Example: Price Waterhouse and the Mixed-Motive Case}

Ann Hopkins was denied partnership in Price Waterhouse, a national professional accounting partnership. ${ }^{232}$ She claimed Price Waterhouse

${ }^{228}$ Cf. Schnapper, supra note 62, at 1147 ("When a new piece of legislation addresses an issue with an increased degree of specificity, it is often impracticable for Congress to review every related or analogous existing statute to insert the same language. Rather than giving such later specific legislation the effect of narrowing earlier laws, the Court should look to the more specific subsequent legislation as a guide to interpreting the earlier more general measures.").

${ }^{229}$ On the countermajoritarian difficulty, see AlEXANDER M. BiCKEL, THE LEAST DANGerous Branch: THE SUPREME COURT AT THE BAR OF POLITICS 16-23 (1962).

${ }^{230}$ See supra note 196.

${ }^{231}$ An example in the opposite direction is found in EEOC v. Arab Am. Oil Co., 499 U.S. 244 (1991) ("Aramco"). In 1983, Congress amended the ADEA in response to several judicial opinions that concluded the ADEA could not be applied extraterritorially to protect from age discrimination American citizens working abroad for American firms. See 29 U.S.C. $\S 623(\mathrm{~h})(1)$ (2000). At least some Congressmembers thought that, by so amending it to specifically authorize extraterritorial coverage, the ADEA would become coextensive with the coverage of Title VII. Aramco, 499 U.S. at 273 n.7 (Marshall, J., dissenting). Nevertheless, in Aramco, the Court held that Title VII did not apply to American citizens working for American companies abroad, relying for support on the fact that Title VII was not similarly amended. See id. at 256.

${ }^{232}$ More accurately, in her first year as a partner candidate, she was "held" for reconsideration and, subsequently, never again proposed as a candidate. See Price Waterhouse v. Hopkins, 490 U.S. 228, 231 and 233 n.1 (1989). 
denied her the opportunity based on her sex. ${ }^{233}$ Price Waterhouse claimed Hopkins had distinct personality problems that alienated her from those with whom she worked, including the claim that she was abusive to employees whom she supervised. ${ }^{234}$ Those personality problems, Price Waterhouse argued, doomed Hopkins's prospects for partnership, not any consideration of her sex. The dispute made its way to the Supreme Court.

In a fractured set of opinions with a four justice plurality, ${ }^{235}$ two separate concurrences, ${ }^{236}$ and a dissent by the remaining justices, ${ }^{237}$ the Court handed Hopkins a victory. The Court ruled that a plaintiff could prevail on a claim pursuant to Title VII in a "mixed-motives" case. ${ }^{238}$ Specifically, the Court found that, even if Price Waterhouse was motivated to deny partnership to Ann Hopkins based on her allegedly negative personality characteristics that were unrelated to her sex, it also was motivated to reject her based Hopkins's failure to live up to stereotypes of proper feminine behavior and characteristics. That reliance on sex stereotypes is prohibited by Title VII. Thus, the four justices in the plurality, as well as Justice O'Connor and Justice White in concurrence, agreed that when a plaintiff shows that the employer relied upon the plaintiff's protected characteristic when it made an adverse employment decision about him or her, the plaintiff has carried his or her burden under Title VII, even if the employer also relied on other, legitimate criteria. ${ }^{239}$

For an interesting first-hand account of the case and its antecedent facts, see ANN Branigar Hopkins, So ORdered: MAKING PARTNER THE HARD WAY (1996).

${ }^{233}$ Price Waterhouse, 490 U.S. at 231.

${ }^{234} I d$. at 234-35.

235 Justices Marshall, Blackmun, and Stevens joined the opinion authored by Justice Brennan. Id. at 230-58.

${ }^{236}$ Justice White and Justice O'Connor each wrote a concurring opinion. Id. at 25879.

${ }^{237}$ Chief Justice Rehnquist and Justice Scalia joined the dissent, which as written by Justice Kennedy. Id. at 279-95.

${ }^{238}$ See id. at 246-47 (using the "mixed-motives case" label). The plurality noted that the idea of a mixed-motives case had its origin in a constitutional employment claim. Id. at 248-49 (citing and discussing Mt. Healthy City Bd. of Ed. v. Doyle, 429 U.S. 274 (1977), in which a public school teacher sued the board of education for firing him in violation of his free speech rights under the First Amendment). Indeed, Justice White relied primarily on this precedent in his concurrence. Id. at 258 (White, J., concurring in the judgment) ("In my view, to determine the proper approach to causation in this case, we need look only to the Court's opinion in [Mt. Healthy]." (citation omitted)).

${ }^{239}$ The judges in the plurality and the two concurring judges used different wording to describe what the plaintiff must show. The plurality indicated that sex needed to play a "motivating part in an employment decision." Price Waterhouse, 490 U.S. at 250 (plurality opinion). Justice Brennan, writing for the plurality, elaborated by saying that the "because of" language means "that gender must be irrelevant to employment decisions." Id. at 240. Justice White would have required a showing that sex was a "substantial factor," Id. at 260 
Nevertheless, the court also held that the employer could entirely escape liability under Title VII by proving an affirmative defense ${ }^{240}$ that it would have made the same challenged employment decision even had it not considered the illegal criterion. ${ }^{241}$

At the root of the plurality's logic was the recognition that the "because of" language in Title VII ${ }^{242}$ did not require a plaintiff to prove that his or her protected status was the "but for" cause of the challenged employment action. Instead, the statute required a lesser causal standard. ${ }^{243}$ The plurality explained: "In saying that gender played a motivating part in an employment decision, we mean that, if we asked the employer at the moment of the decision what its reasons were and if we received a truthful response, one of those reasons would be that the applicant or employee was a woman."244 The four justices in the plurality and two concurring justices

(White, J., concurring), as would have Justice O’Connor. Id. at 265 (O’Connor, J., concurring).

${ }^{240}$ Justice O'Connor did not view this escape hatch as an affirmative defense as the plurality did. Instead, she believed that when a plaintiff carried his or her burden under the mixed motives case, the burden of persuasion shifted to the defendant to prove that the illegal criterion was not the "but for" cause of the employment decision. See id. at 263 (O’Connor, J., concurring). The dissent, likewise, ridiculed the plurality's characterization of it as an affirmative defense, calling the plurality's approach "nothing more than a label." Id. at 286 (dissenting opinion). See infra note 243 for a discussion of why this disagreement was related to a disagreement over the causal standard required to show a violation of Title VII.

${ }^{241} I d$. at 244-45 (plurality opinion). This is known as the "same decision defense." A related holding of the Court was that the defendant's burden of proof under the same decision defense was to make its showing by a preponderance of the evidence. $I d$. at 254 (plurality opinion). The court below had required clear and convincing evidence. Id.

${ }^{242}$ See 42 U.S.C. $\$ 2000 \mathrm{e}-2(\mathrm{a})(1)$ (2000) ("It shall be an unlawful employment practice for an employer . . . to fail or refuse to hire or to discharge any individual, or otherwise to discriminate against any individual with respect to his compensation, terms, conditions, or privileges of employment, because of such individual's race, color, religion, sex, or national origin ....") (emphasis added).

${ }^{243}$ There was not complete agreement about what that lesser standard should be among the justices who nevertheless agreed that the "but for" standard was not required. Notably, Justice O'Connor distanced herself from the plurality on this point as well, arguing that the language of Title VII did, in fact, require "but for" causation, but was silent as to which party carried the burden of persuasion (and the attendant risk of nonpersuasion) regarding "but for" causation. Price Waterhouse, 490 U.S. at 262-63 (O'Connor, J., concurring in the judgment) ("Thus, I disagree with the plurality's dictum that the words 'because of" do not mean 'but for' causation; manifestly they do.") The dissent adopted the same reading of the plurality's framework as Justice O'Connor, but disagreed that the burden shift was appropriate. Id. at 285-86 (dissenting opinion). See supra note 240 for a related discussion of the plurality's and Justice O'Connor's disagreement over whether a mixed motives case involves an affirmative defense or a shift in the burden of persuasion.

${ }^{244}$ Price Waterhouse, 490 U.S. at 250. But see Linda Hamilton Krieger, The Content of Our Categories: A Cognitive Bias Approach to Discrimination and Equal Employment 
agreed that the district court and the court of appeals in Hopkins's case had not erred in finding that Hopkins presented sufficient evidence to carry her burden under that lesser causal standard. ${ }^{245}$ The plurality argued that once sex was shown to be a motivating part of the decision, as Hopkins had done, the plaintiff"s burden of proof was satisfied, because "when . . . an employer considers both gender and legitimate factors at the time of making a decision, that decision was 'because of' sex and other, legitimate considerations - even if we may say later, in the context of litigation, that the decision would have been the same if gender had not been taken into account." 246 This, of course, stands in stark contrast to the burden placed on the plaintiff under the McDonnell Douglas framework, ${ }^{247}$ which seemingly requires the plaintiff to show that the illegal motive was the employer's one, true motive. ${ }^{248}$

It was Justice O'Connor's concurrence, however that lower courts and many commentators treated as Price Waterhouse's operative holding, because her approach was the most restrictive. ${ }^{249}$ Justice O'Connor

Opportunity, 47 STAN. L. REV. 1161, 1172 (1995) (arguing that this standard erroneously conflates motive and intent, as well as that it is inconsistent with a cognitive understanding of discrimination, in which an employer likely cannot accurately pinpoint the reasons for its decisions, including stereotypes, which operate on an automatic and unconscious level).

${ }^{245}$ See id. at 251 (plurality opinion); $i d$. at 259 (White, J., concurring in the judgment); $i d$. at 272 (O'Connor, J., concurring in the judgment).

Hopkins presented evidence of sex-based comments made directly to her (e.g., that she should "walk more femininely, talk more femininely, dress more femininely, wear makeup, have her hair styled, and wear jewelry"), id. at 235, sex-based comments that were included in evaluation forms solicited from the Price Waterhouse partners, id., and expert testimony of a social psychologist regarding the mechanics and presence of sex stereotyping in the evaluation process, $i d$. at 235-36.

${ }^{246} I d$. at 241.

247 See McDonnell Douglas v. Green, 411 U.S. 792 (1973). The McDonnell Douglas framework is often used to prove and to evaluate the evidence in cases claiming disparate treatment employment discrimination pursuant to Title VII, as well as the ADEA, and the Americans With Disabilities Act of 1990. See, e.g., Raytheon Co. v. Hernandez, 540 U.S. 44, 124 S. Ct. 513, 517-18 (2003) (analyzing an ADA claim using the McDonnell Douglas framework); Reeves v. Sanderson Plumbing Prods., Inc., 530 U.S. 133, 142 (2000) (assuming, but not holding, that the McDonnell Douglas framework applies in ADEA cases); O’Connor v. Consolidated Coin Caterers Corp., 517 U.S. 308, 311 (1996) (same).

${ }^{248}$ Price Waterhouse, 490 U.S. at 246-47.

249 See City of Lakewood v. Plain Dealer Publ'g Co., 486 U.S. 750, 765 n.9 (1988) ("[W]hen no single rationale commands a majority, "the holding of the Court may be viewed as that position taken by those Members who concurred in the judgmen[t] on the narrowest grounds." (quoting Marks v. United States, 430 U.S. 188, 193 (1977))). But see Benjamin C. Mizer, Note: Toward a Motivating Factor Test for Individual Disparate Treatment Claims, $100 \mathrm{MICH}$. L. REV. 234 (2001) (arguing that it is odd to treat as controlling a proposition (i.e., the requirement of direct evidence) that was clearly not endorsed by a majority of the court and citing Tyler v. Bethlehem Steel Corp., 958 F.2d 
explained that she would require a Title VII plaintiff to produce "direct evidence" ${ }^{250}$ that the plaintiff"s protected status was a substantial factor in the employer's challenged decision, before the burden would shift to the employer to justify that decision absent the illegal consideration. ${ }^{251}$ The plurality made no such explicit distinction between direct and circumstantial evidence to separate mixed-motives cases from "pretext" cases. Even so, Justice O'Connor failed to provide a clear distinction between the two types of evidence. She defined her notion of direct evidence in the negative (i.e., citing a few examples of what it was $\operatorname{not}^{252}$ ) and then explained that Hopkins's evidence fit the bill. ${ }^{253}$ Thus, the bifurcation of individual disparate treatment law between a Price Waterhouse mixed-motives case and a McDonnell Douglas pretext case was premised on the character of the plaintiff's evidence, direct or circumstantial. Unsurprisingly, the lower courts struggled, without success, for consistency under this paradigm. ${ }^{254}$

Price Waterhouse, like Wards Cove, was in Congress's crosshairs in the early 1990s. And, like Wards Cove, it was overridden in part by the 1991 Act. $^{255}$ Specifically, Congress took aim at Price Waterhouse by allowing a

1176, 1183 (2d Cir. 1992), for making the same argument).

${ }^{250}$ Courts have had a notoriously difficult time in employment discrimination cases identifying direct evidence or defining the difference between direct and circumstantial evidence. One commentator calls the distinction "illusory." See Stephen W. Smith, Title VII's National Anthem: Is there a Prima Facie Case for the Prima Facie Case, 13 LAB. LAW. 367 (1997). Another questions whether true direct evidence of an employer's intent to discriminate is possible to find, because even an admission of discriminatory intent by the employer or an employer's agent requires the factfinder to infer that the decisionmaker knew his or her own mind and motives and is able to report accurately those motives. See Deborah C. Malamud, The Last Minuet: Disparate Treatment After Hicks, 93 MicH. L. REV. 2229, 2321 n.290 (1995).

${ }^{251}$ Price Waterhouse, 490 U.S. at 276 (O'Connor, J., concurring in the judgment) ("In my view, in order to justify shifting the burden on the issue of causation to the defendant, a disparate treatment plaintiff must show by direct evidence that an illegitimate criterion was a substantial factor in the decision.").

252 Id. at 277 (explaining that "stray remarks in the workplace," "statements by nondecisionmakers," and "statements by decisionmakers unrelated to the decisional process" are each, "standing alone," not direct evidence for purposes of shifting the burden of causation to the defendant under the mixed-motives approach).

${ }^{253} I d$.

${ }^{254}$ See, e.g., Robert A. Kearney, The High Price of Price Waterhouse: Dealing with Direct Evidence of Discrimination, 5 U. PA. J. LAB. \& EMP. L. 303 (2003) (discussing the various approaches to classifying direct and circumstantial evidence that developed after Price Waterhouse and arguing that the distinction between mixed-motives and pretext cases results in courts undervaluing evidence of biased oral comments that are not considered "direct" evidence)

255 See H.R. REP. No. 102-40, at 45-48 (1991) (reporting on a substantially similar earlier version of the Civil Rights Act of 1991 and explaining the "need to overturn Price Waterhouse"). 
plaintiff to prove a violation of the statute through the lesser "motivating factor" causation standard. ${ }^{256}$ Furthermore, Congress converted the "same decision" defense, ${ }^{257}$ as announced in Price Waterhouse, from an affirmative defense regarding liability to a remedy limitation. Section 107 of the 1991 Act, which amended sections $703^{258}$ and $706^{259}$ of Title VII, was the vehicle for this change.

As it did in response to Wards Cove, Congress amended Title VII in response to Price Waterhouse's restrictive interpretation of language that appears in identical form in the ADEA. ${ }^{260}$ And, again, Congress did not amend the ADEA in the 1991 Act in response to Price Waterhouse. Smith's Bizarro statutory stare decisis doctrine would find the fact that Congress did not amend the ADEA in response to Price Waterhouse determinative. The operative holding of Price Waterhouse would apply with continuing force to the ADEA. ${ }^{261}$ But that is wholly unsatisfying.

${ }^{256}$ Presumably, Congress's use of "motivating factor" and not "substantial motivating factor" was not an oversight, but was a specific choice of the plurality's - not Justice O'Connor's and Justice White's - view of the causal standard. See supra note 239.

257 See supra note 241 and accompanying text.

${ }^{258}$ Section 703(m) now reads:

Except as otherwise provided in this title, an unlawful employment practice is established when the complaining party demonstrates that race, color, religion, sex, or national origin was a motivating factor for any employment practice, even though other factors also motivated the practice.

42 U.S.C. $\S 2000 \mathrm{e}-2(\mathrm{~m})(2000)$.

${ }^{259}$ As amended, section 706(g)(2)(B) now reads:

On a claim in which an individual proves a violation under section $2000 \mathrm{e}-2(\mathrm{~m})$ of this title [section $703(\mathrm{~m})$ ] and a respondent demonstrates that the respondent would have taken the same action in the absence of the impermissible motivating factor, the court -

(i) may grant declaratory relief, injunctive relief (except as provided in clause (ii)), and attorney's fees and costs demonstrated to be directly attributable only pursuant to a claim under section $2000 \mathrm{e}-2(\mathrm{~m})$ of this title [section $703(\mathrm{~m})$ ]; and

(ii) shall not award damages or issue an order requiring any admission, reinstatement, hiring, promotion, or payment, described in subparagraph (A) [dealing with backpay and other victim-specific relief].

Id. $\S 2000 \mathrm{e}-5(\mathrm{~g})(2)(\mathrm{B})$.

${ }^{260}$ Compare 42 U.S.C. $§ 2000 \mathrm{e}-2(\mathrm{a})(1)$ (2000) with 29 U.S.C. $\S 623(\mathrm{a})(1)(2000)$.

261 To complicate matters, there is an argument that the RFOA provision obviates the question, because it is a safe harbor for employers in mixed-motives cases. So, there really is no "mixed-motives" case under the ADEA. See, e.g., Smith, 544 U.S. at 253 (O'Connor, J., dissenting) ("[T]he RFOA provision also plays a distinct . . . role in "mixed-motive" cases. In such cases, an adverse action taken in substantial part because of an employee's age may be 'otherwise prohibited' by $\S 4(a)$. The RFOA exemption makes clear that such conduct is nevertheless lawful so long as it is 'based on' a reasonable factor other than age." (internal citations omitted)); Transcript of Oral Argument at 51, Smith, 544 U.S. 228 (No. 03-1160), available at http://www.supremecourtus.gov/ oral_arguments/argument_transcripts/03-1160.pdf. 
Justice O'Connor's concurring opinion - in particular the direct vs. circumstantial evidence issue - has been widely criticized and, in fact, has recently been revealed as likely wrong in the first place. In Desert Palace, Inc. v. Costa, ${ }^{262}$ the Supreme Court granted certiorari to answer "whether a plaintiff must present direct evidence of discrimination in order to obtain a mixed-motive instruction under Title VII . . ., as amended by the [1991 Act]."263 Its answer was a resounding, unanimous ${ }^{264}$ no. The Court found that a plaintiff is entitled to have the jury instructed according to the motivating factor standard of section $703(\mathrm{~m})^{265}$ when he or she has produced sufficient evidence to support that contention, without regard to whether that evidence is direct or circumstantial. ${ }^{266}$

The Court based its holding on reading the statute according to three basic principals. First, the text of the statute makes no mention of a direct evidence requirement. $^{267}$ Second, 703(m) applies if the plaintiff "demonstrates" an impermissible motive. "Demonstrates" is a defined term in the statute: meeting the burdens of production and persuasion. ${ }^{268}$ The Court reasoned that it must interpret that term accurately and consistently. Accuracy required that the Court not read a direct evidence requirement into the definition without clear intent from Congress that it should. ${ }^{269}$ The Court found no such indication of congressional intent. ${ }^{270}$ Moreover, consistency required that the use of the term "demonstrates" in section $703(\mathrm{~m})$ be given the same meaning in section $706(\mathrm{~g})(2)(\mathrm{B})$, the same decision defense. Notably, the defendant argued that it had no direct evidence requirement to prove the same decision defense. ${ }^{271}$ Thus, the Court refused to interpret the same term differently in the two related

262539 U.S. 90 (2003).

${ }^{263}$ Id. at 92 .

${ }^{264}$ Note that even Justice O'Connor agreed that her direct evidence standard from Price Waterhouse was not incorporated in section $703(\mathrm{~m})$; however, she did write a separate concurring opinion to reiterate her view that the Price Waterhouse direct evidence rule was appropriate prior to being supplanted by Congress. Id. at 102 (O'Connor, J., concurring).

265 The Court continued to use the term mixed-motives instruction rather than motivating factor instruction despite the absence of the former in the statutory language. See id. at passim.

${ }^{266} I d$. at 101 ("In order to obtain an instruction under [section 703(m)], a plaintiff need only present sufficient evidence for a reasonable jury to conclude, by a preponderance of the evidence, that 'race, color, religion, sex, or national origin was a motivating factor for any employment practice."”).

${ }^{267}$ Id. at 98-99 ("On its face, the statute does not mention, much less require, that a plaintiff make a heightened showing through direct evidence.”).

${ }^{268}$ See 42 U.S.C. $\$ 2000 \mathrm{e}(\mathrm{m})(2000)$.

${ }^{269}$ Costa, 523 U.S. at 99.

${ }^{270} \mathrm{Id}$.

${ }^{271} I d$. at 101 . 
sections of Title VII without some clear indication from Congress that it should. $^{272}$ Finally, the Court relied on the "conventional rule of civil litigation" that circumstantial evidence is no less adequate or convincing than direct evidence. ${ }^{273}$ The Court drove home its point with the following: "The reason for treating circumstantial and direct evidence alike is both clear and deep-rooted: 'Circumstantial evidence is not only sufficient, but may also be more certain, satisfying, and persuasive than direct evidence.",274 As a result, Justice O'Connor's evidentiary dichotomy was undone. $^{275}$

Nevertheless, lower courts still struggle with whether Price Waterhouse's formulation of the mixed-motives theory applies to the ADEA. ${ }^{276}$ Bizarro statutory stare decisis would short circuit any reasoned consideration of the question.

\section{An Alternative Approach: Putting Bizarro to Rest}

The real question that the Court should have addressed in Smith )and that Courts should consider with regard to Price Waterhouse) was not whether Congress's inaction with regard to the ADEA should be read as an endorsement of Wards Cove. Instead, the Court should have focused on the appropriate structure of a disparate impact claim, including the allocation of the burdens of proof, according to the text, purpose, and legislative history of the ADEA. ${ }^{277}$ This approach is really just statutory interpretation in the first instance. Perhaps the overridden interpretation is the correct one; however, without indicators in the text, purpose, or history of the related statute that are even stronger indicators of correctness of the interpretation

${ }^{272} I d$.

${ }^{273} I d$. at 100 .

${ }^{274}$ Id. (quoting Rogers v. Missouri Pacific R. Co., 352 U.S. 500, 508 n. 17 (1957)).

${ }^{275}$ Justice O'Connor wrote a brief concurring opinion in Costa to note that she agreed with the majority opinion in that the 1991 Act's amendments "codified a new evidentiary rule for mixed-motive cases arising under Title VII." Id. at 102 (O'Connor, J., concurring). She maintained, however, that the requirement in her concurrence to trigger the mixedmotives analysis was the appropriate rule prior to the amendments. Id.

${ }^{276}$ Compare Rachid v. Jack in the Box, Inc., 376 F.3d 305, $312\left(5^{\text {th }}\right.$ Cir. 2004) (finding applicable to the ADEA the Costa conclusion that circumstantial evidence may be used to support a mixed-motives claim) with Glanzman v. Metropolitan Mgmt. Corp., 391 F.3d 506 n. 3 ( $3{ }^{\text {rd }}$ Cir. 2004) ("Because the Civil Rights Act of 1991 does not apply to ADEA cases ... we continue to apply the Price Waterhouse test in order to resolve ADEA cases.").

${ }^{277}$ Cf. Eskridge, Interpreting, supra note 121, at 97 ("The formal question [with which the Court should concern itself in the 1989 case of Patterson v. McLean Credit Union] is whether the text and legislative history of section 1981 itself support Runyon [ $v$. McCrary]."). 
than were present in the statute for which the interpretation was overridden, it should not be applied. The text, purpose, and history of the ADEA do not make a strong case for applying Wards Cove. In fact, the presumption against the overridden interpretation should be even stronger in the context of the civil rights and equal employment opportunity statutes, because the Supreme Court's limiting interpretations have been consistently repudiated Congress. ${ }^{278}$ The Court should have should have been particularly loathe to resurrect Wards Cove, which had already met with disapproval. ${ }^{279}$

The Court in Smith should have recognized that there was no strong justification for treating Wards Cove like binding precedent. ${ }^{280}$ It had not induced any significant reliance by either parties or lawmakers. Resurrecting Wards Cove did not significantly enhance the consistency or coherence of the law. Whether the ADEA even allowed disparate impact

278 See Schnapper, supra note 62, at 1098 (quoting Rep. Ford from 137 CONG. REC. H9533 (daily ed. Nov. 7, 1991) as indicating that the 1991 Act would send "a powerful message that the American people reject the Supreme Court's narrow and crabbed interpretation of civil rights laws generally and equal employment opportunity statutes specifically) and 1100 (referring to "judicial recidivists").

279 The interaction between the courts and Congress leading up to and following Aramco could have provided guidance to the Court in Smith. In that case, the Court had to determine whether Congress intended Title VII to apply extraterritorially to American citizens working for American companies abroad. Aramco, 499 U.S. 244, 246 (1991). In interpreting Title VII not to have extraterritorial reach, the Court relied on the fact that Congress had previously amended the ADEA to clarify its extraterritorial application after several courts had interpreted it not to apply outside the United States. Congress did not likewise amend Title VII. Id. at 258. See also supra note 231 (explaining that some Congressmembers were convinced that the amendment to the ADEA was necessary to make it coextensive with Title VII). Aramco was not an application of Bizarro statutory stare decisis because the Court only mentioned the ADEA amendment to "buttress" its conclusion, noting that it was evidence that Congress understood how to make its intent of extraterritorial application clear. Id. But that falls short of formally granting statutory stare decisis to the limiting interpretations of the ADEA that prompted Congress to amend it. So, Congress narrowly interpreted Title VII, refusing to recognize that the amendment to the ADEA was a message that Congress intended the federal equal employment opportunity statutes to have broad remedial application. In the end, Congress had to override Aramco in the 1991 Act to clarify its intent for Title VII to apply extraterritorially. See Pub. L. No. 102-166, 105 Stat. 1071, §109 (codified at 42 U.S.C. $§ 2000$ e(f) (2000)). Some give-and-take between the Court and Congress is inevitable. But, the seemingly continual cycle of crabbed and limiting interpretations of the civil rights acts by the Court followed by Congress's corrective legislation is ultimately a waste of resources. The Court should be learning its lesson and adapting its interpretive approach to these statutes accordingly. See generally Schnapper, supra note 62.

${ }^{280}$ As argued in supra note 222, Wards Cove was not a building block interpretation of the language at issue in Smith. Even if there were an argument that Wards Cove was a building block interpretation, Congress clearly indicated its disapproval of the interpretation, a particularly compelling reason not to find any meaning in congressional inaction according to Eskridge. See Eskridge, Interpreting, supra note 121, at 120. 
claims was an open question and resulted in a circuit split, so Smith represented a watershed moment and starting point, rather than a continuation of a consistent interpretation. In addition, following the 1991 Act amendments to Title VII, the coherence or horizontal continuity between Title VII and the ADEA was not enhanced by the application of Wards Cove.

Moreover, the Court should have recognized that Congress overcame significant obstacles of legislative inertia to pass the 1991 Act and repudiate Wards Cove. ${ }^{281}$ To expect that Congress could (or would) overcome those same obstacles to head off what, at the time, was at most a conjecture that Wards Cove would be applied to the ADEA asks too much of Congress. That is particularly true when the interest groups who are most interested in the fate of the ADEA did not have significant motivation to lobby for a similar amendment to the ADEA.

The Court should have done the typical work of courts and interpreted the language of $\S 4(\mathrm{a})(2)^{282}$ - especially with reference to its interaction with the RFOA language in $\S 4(\mathrm{f})(1)^{283}$ - in the first instance, as it would have in the absence of Wards Cove. In particular, the Court should have recognized that the RFOA provision in the ADEA not only narrowed the scope of the disparate impact doctrine as applied to the ADEA, ${ }^{284}$ but also alleviated many of the concerns that animated the Wards Cove decision. Those concerns resulted in the requirement that a plaintiff disaggregate employer decisionmaking to identify the specific employer practice that causes an adverse impact, as well as the shift of the burden of proof of business necessity away from the employer and onto the plaintiff. Because the RFOA provision allays these concerns, it was improper for the court to rely on Wards Cove.

For instance, the Court was concerned that "the failure to identify [a] specific practice being challenged is the sort of omission that could 'result in employers being potentially liable for "the myriad of innocent causes that may lead to statistical imbalances ....".,285 Perhaps that was a valid concern under Title VII when Wards Cove was decided. The fear was that the employer would find it exceedingly difficult to prove business necessity as an affirmative defense, as well as insuring that no less restrictive alternative could have served the same interest. ${ }^{286}$ Perhaps not. $^{287}$

\footnotetext{
${ }^{281}$ See supra Part III.B.1.a. (discussing the inertial forces Congress was dealing with when enacting the $1991 \mathrm{Act})$.

28229 U.S.C. $\S 623(\mathrm{a})(2)(2000)$.

${ }^{283}$ Id. $\S 623(\mathrm{f})(1)$.

${ }^{284}$ Smith, 544 U.S. at 240 ("[T] he scope of disparate-impact liability under ADEA is narrower than under Title VII.”).

${ }^{285} I d$. at 241 (quoting Wards Cove v. Atonio, 490 U.S. 642, 657 (1989)).

${ }^{286}$ See 42 U.S.C. $\S 2000 \mathrm{e}-2(\mathrm{k})$ (2000).
} 
Regardless, the less exacting RFOA provision makes those fears even less warranted. Employers could be expected to defend, for instance, its overall hiring process as being reasonable, even if portions of it are not necessary or particularly easy to validate from a business necessity standpoint. ${ }^{288}$

Similarly, though Wards Cove structured disparate impact claims so that the plaintiff-employee retained the ultimate burden of proof throughout, a resort to the plain text of the ADEA would suggest a different result. The RFOA provision ${ }^{289}$ in the ADEA appears to be an affirmative defense to the "limit, segregate, or classify" language of $\S 4(\mathrm{a})(2) .{ }^{290}$ The bona fide occupational qualification defense, ${ }^{291}$ which is in the same subsection as the RFOA provision and which is written in parallel language, is an affirmative defense. $^{292}$ If the in pari materia canon ${ }^{293}$ has any force, it should here. In addition, courts have treated the RFOA as an affirmative defense in the disparate treatment context. ${ }^{294}$ How odd it would be if the same statutory provision placed the burden on different parties based on the theory of

${ }^{287}$ Clearly Congress was not wholly moved by these concerns as they relate to Title VII. The 1991 Act amendments allowed a plaintiff to make a showing of disparate impact without pinpointing the "particular employment practice" that caused the adverse impact if the plaintiff "can demonstrate to the court that the elements of a[n employer's] decisionmaking process are not capable of separation for analysis." Id.

${ }^{288}$ See, e.g., Meacham v. Knolls Atomic Power Lab., Docket Nos. 02-7378-cv(L), 027474-cv(XAP), 2006 U.S. App. LEXIS 20941 at*28-*29 (2d Cir. Aug. 14, 2006) (finding that employer's process of identifying employees to be laid off under an involuntary reduction in force was reasonable, in part because it was not arbitrary). Meacham illuminates an interesting conundrum. The process for determining the layoffs included managers' subjective evaluations of employees' "criticality" and "flexibility." Id. at *27. The employer's oversight of the managers' discretion under the RIF was patchy and generally shoddy. $I d$. at $* 28$. Thus, it was possible, if not likely, that managers' biases against older workers crept in to that subjective step. Yet, because the process was not wholly arbitrary, it was reasonable and fulfilled the RFOA provision of the ADEA. Id. at *29. One is left with the impression that, under the RFOA standard, the employer is better off employing a subjective layoff process that incorporates popular management jargon like "criticality," which opens the door for biases against older workers to take root, than engaging in a wholly random process, like drawing names out of a hat. The latter is arbitrary and, thus, perhaps not reasonable, even though it is more effective at insulating employees from conscious or subtle bias..

28929 U.S.C. $\S 623(f)(1)$.

${ }^{290} I d . \S 623(\mathrm{a})(2)$. See supra note 187.

${ }^{291}$ Id. § 623(f)(1) ("It shall not be unlawful for an employer . . . to take any action otherwise prohibited under [the ADEA] where age is a bona fide occupational qualification reasonably necessary to the normal operation of the particular business ....").

${ }^{292}$ See Smith, 544 U.S. at 233 n.3.

${ }^{293}$ See supra note 106 and accompanying text.

294 E.g., Criswell v. Western Airlines, Inc., 709 F.2d 544, 552 (1983) ("The 'reasonable factors' defense appears alongside the BFOQ exception in the ADEA and is an affirmative defense for which the employer bears the burden of proof."). 
recovery under which the parties were operating. To treat the RFOA provision as allocating the burden of proof to the employee to prove that the employer's practice is unreasonable contradicts prior interpretations of the language, ignores an important canon of construction, and - most disturbingly - elevates the policy preferences of the Court as announced in Watson and Wards Cove over the plain language of the ADEA. ${ }^{295}$

These differences from Title VII should have led the court to recognize that, in the absence of a justification for a strong stare decisis rule in Smith, the Court should not have relied on Wards Cove, but instead should have interpreted the language in the first instance. Had the Court done so, it would have avoided the Bizarro nature of its invocation of statutory stare decisis and the potential problems associated with it.

Similarly, courts should not simply presume that Price Waterhouse controls ADEA mixed-motives cases. Instead, courts should recognize that Congress has disapproved of Price Waterhouse and that the Supreme Court has practically rejected Justice O'Connor's requirement that a plaintiff present direct evidence of an unlawful motive.

\section{CONCLUSION}

In Smith the Court aimed its judicial "duplicating ray," the consistency presumption, at the traditional doctrine of heightened statutory stare decisis and created a Bizarro brand, resuscitating an otherwise deservedly dead and gone Wards Cove in the process. None of the justifications for enhanced statutory stare decisis supports the application of the Bizarro version. Instead, the criticisms of the doctrine are typically even stronger when applied to Bizarro statutory stare decisis. In particular, Bizarro statutory stare decisis places an unwarranted burden on Congress to identify every possible statutory setting where a decision of the Court could have analogical force and amend those statutes to insure the ultimate demise of the disfavored interpretation. That sort of allocation of the burden of the work load between the Court and the Congress is both dangerous and counterintuitive. To the extent that Congress acts decisively to override the Court's statutory interpretation of specific legislation, the Court should not feel empowered to automatically apply the repudiated interpretation in other contexts, forcing Congress to head off the Court's implementation of its

${ }^{295}$ See Meacham v. Knolls Atomic Power Lab., Docket Nos. 02-7378-cv(L), 02-7474$\operatorname{cv}(X A P), 2006$ U.S. App. LEXIS 20941 at *17 (2d Cir. Aug. 14, 2006) ("Any other interpretation [than that the employee bears the burden of showing the employer's justification for its practice is unreasonable] would compromise the holding in Wards Cove that the employer is not to bear the ultimate burden of persuasion with respect to the 'legitimacy' of its business justification. (emphasis added)). 
own policy choices. Instead, the burden should be on the Court to engage in real interpretation of the language. While there may be instances in which the analogical force of the prior, overridden interpretation in a new statutory setting is so strong it should supersede Congress's disapproval, Wards Cove as applied to the ADEA was not that case. Furthermore, one would expect such cases to be rare. At the very least, the Court should feel compelled to explain why the overridden interpretation is so appropriate in the subsequent statutory context, despite it earlier disapproval by Congress.

As a result of the Courts' use of the Bizarro version of statutory stare decisis in Smith, the Court has raised the specter of additional applications in the near future. In the 1991 Act alone, Congress overrode a number of interpretations of provisions in Title VII that have analogs in the ADEA. Thus, each of these instances may result in the undoing of some of the work done by Congress in the 1991 Act, if Bizarro statutory stare decisis were applied as it was in Smith. The Court should instead take on the role of interpreting statutes in the way it normally would and not rely on rejected interpretations.

The imperfect duplicate of the enhanced rule of statutory stare decisis that the Court invoked to apply Wards Cove in Smith is of little value. Bizarro statutory stare decisis upsets the balance of power and the appropriate workload between the Court and Congress. It illegitimately excuses the Court from its duty of engaging in reasoned and well-grounded interpretation of statutory language. Thus, like Bizarro in the Superman comics, it should be destroyed. 